\title{
Business Strategies and Management Accounting in Response to Climate Change Risk Exposure and Regulatory Uncertainty
}

\author{
Binh Bui \\ Victoria University Wellington \\ Charl de Villiers \\ The University of Auckland and University of Pretoria \\ charl.devilliers@auckland.ac.nz
}

\author{
PLEASE CITE AS: \\ Bui, B. \& de Villiers, C. 2017. Business Strategies and Management \\ Accounting in Response to Climate Change Risk Exposure and Regulatory \\ Uncertainty. The British Accounting Review, 49(1), 4-24.
}

\begin{abstract}
This study aims to theorise and foster a better understanding of the strategies organisations adopt to respond to the risks and opportunities emerging from changing government climate change policies and the supporting management accounting adopted. Data include interviews and archival documents from five New Zealand electricity generators. We construct a theoretical framework that links climate change risks and opportunities to strategic responses. Climate change risk exposure increased during the period due to changes in the estimation/perception of climate change risks, market opportunities and regulatory uncertainty. Organisations' strategies changed in response, moving from a stable strategy to different combinations of anticipatory, proactive, and creative strategies, and finally regressing to a reactive strategy. Carbon management accounting changed to support the new strategy adopted in each time period. Long term physical and monetarised accounts for sustainability and extensive use of carbon information were prevalent during periods when the companies employed a proactive or creative strategy. In contrast, short-term physical accounts for unsustainability and limited use in decision-making were observed when the companies adopted stable, anticipatory or reactive strategies. Regulatory uncertainty was found to be the major constraint to a proactive strategy and carbon management accounting development in response to climate change.
\end{abstract}

Paper type: Empirical

Keywords: climate change, risk, business strategy, carbon management accounting

Acronyms

CMA - Carbon management accounting

CC - Climate change 


\section{Introduction}

The increasing complexity and changes characterising today's business environment mean that significant attention is being paid by academics and professionals to managing business risk (Arena et al., 2010; Bhimani, 2009; Paape \& Speklé, 2012; Power, 2004). The association between risk management and management accounting has been acknowledged in the literature, but few studies provide empirically derived insights (e.g. Mikes, 2009; Woods, 2009). Risk management refers to the identification, measurement, assessment and treatment of not only risks with negative consequence on organisational performance, but also opportunities that can increase organisational value (Committee of Sponsoring Organizations of the Treadway Commission (COSO), 2004). Both risk management and management accounting have the capacity to change organisational behaviour and activities (Bhimani, 2009). Risk management strategies can set new boundaries that limit or enable organisational activities, affecting organisational change (Bhimani, 2009; Mikes, 2009). Similarly, management accounting can gain organisational significance through generating organisational debate and acquiring a language that is considered legitimate and important by top management (Burchell et al., 1980). When certain forms of management accounting are used to monitor and manage risks, they acquire a level of organisational significance, being able to influence the success and direction of organisational strategies (Simons, 1991). Therefore, management accounting that focusses on sustainability performance can promote organisational change by addressing the risks and opportunities associated with sustainability (Schaltegger, 2011).

The introduction of an emissions tax or an emissions trading scheme (ETS) to combat climate change (CC) constitutes additional business risk (CERES, 2007; Deloitte, 2007; Reinaud, 2005). Before and during the introduction of an ETS, businesses face the uncertainty of how much and when additional costs will be imposed. Once emissions trading starts, there are risks of changing carbon credit prices, uncontrolled and fluctuating emissions levels, potential penalties associated with inaccurate carbon surrendering ${ }^{1}$ and reporting, and the impact on competitiveness. While organisations may respond to these risks with different strategies (Kolk \& Pinkse, 2005), little empirical insight is available regarding these strategic responses (Kolk et al., 2008). The strategy adopted in response to ETS regulatory uncertainty and risk drives the carbon management accounting (CMA) introduced. CC is considered a strategic risk for many organisations (Ascui \& Lovell, 2011; Burritt et al., 2011; Schaltegger \& Csutora, 2012) but few studies examine these links and, therefore, they are not well understood (Mikes, 2009; Woods, 2009).

This study is motivated by the need to better understand the relationships among CC risks, strategies to manage these risks, and carbon-related management accounting. In addition, the paper responds to recent calls in the literature for more insight into the role of management accounting in integrating sustainability into business strategy and risk management practices (Gond et al., 2012; Henri \& Journeault, 2010; Pérez et al., 2007). Therefore, this study aims to theorise and foster a better understanding of i) the changes in the strategy companies adopt to respond to changing ETS-related risk exposure, and ii) the associated changes in carbon-related management accounting.

\footnotetext{
${ }^{1}$ In an emissions trading scheme, organisations are required to 'pay for' their emissions by surrendering carbon credits/allowances equal to their emissions.
} 
We do this by investigating how change in $\mathrm{CC}$ exposure, comprising of $\mathrm{CC}$ risks, market opportunities, and regulatory uncertainties, drive modifications in corporate strategies and carbon accounting.

We define CC risk as including all manufactured risks (see Beck, 1992) around changing fuel prices and the related changing valuation of generation equipment, the direct cost of carbon emissions, windfall gains for renewable generation capacity, societal pressures and customer reactions, competitive risks, and opportunities to invest in new renewable generation. Therefore, we include both risks and opportunities in our definition of CC risk. According to Knight (1921), risk can be distinguished from uncertainty, with risk being present when the probability of future events can be measured, and uncertainty being present when the likelihood of future events are indeterminable or incalculable. Regulatory uncertainty relates to the "inability to predict the future state of the regulatory environment" (Hoffmann et al., 2009, p. 1229). Companies choose response strategies to CC and CC policies based on their estimation and quantification of $\mathrm{CC}$ risks. However, regulatory uncertainty may hamper their ability to make decisions and choose appropriate responses (Hoffmann et al., 2009). Given that Hoffman et al. (2009) regards the concept of regulatory uncertainty as important enough to separately define it, as well as the prominence of regulatory risk in our case analyses, we regard regulatory uncertainty to be a separate construct that does not form part of the concept of CC risk as used in this study.

We use contingency theory and take a risk perspective to construct a theoretical framework based on our case data and the categorisations of environmental strategies proposed in the prior literature. We use this framework to analyse in-depth interviews and archival documentation relating to the five biggest electricity generators in New Zealand in order to better understand corporate strategic and accounting responses to a particular risk exposure context. We modify the framework based on our findings to incorporate the preferred management accounting systems used depending on chosen strategies.

This paper makes several contributions to the literature. First, we construct a framework that links CC risks and opportunities with appropriate strategic responses. This framework also identifies the activities and functional focus for each strategic response. Based on this framework, we identify the contingency fit between CC exposure and risk management strategies. Less active strategies, including stable, anticipatory and reactive strategies, dominate when the risk exposure is low, medium, or decreasing. When risk exposure and market opportunities increase, companies move to proactive and creative strategies to manage their carbon performance.

Second, we show the impact of regulatory uncertainty on risk management strategies. Our case study organisations adopt different strategic responses from those predicted by the prior literature, and these differences can be explained by differences in regulatory uncertainty. High levels of regulatory uncertainty generally prompt companies to adopt less proactive strategies.

Third, we find that carbon management accounting is designed to match the chosen risk management strategy (that responds to changes in risk). More reactive strategies rely on short-term physical accounts for unsustainability that are little used in decision-making. As organisations move to more proactive strategies they emphasize 
long term physical and monetarised accounts for sustainability improvement that are used extensively in decision-making and strategic renewal. Carbon emission reduction is most likely when organisations adopt proactive and creative strategies, where management accounting focusses on accounts for sustainability.

Finally, we extend the prior literature (e.g. Schaltegger, 2012) by considering societal, economic and regulatory pressures. The regression of strategies from proactive to reactive contrasts with much of the prior literature that reports an ever increasing emphasis on sustainability. We also emphasise the importance of regulatory certainty and strong risk and opportunity signals sent by government policies in order to incentivise organisations to take definitive steps in their strategies and carbon accounting systems.

\section{BACKGROUND}

\subsection{Development of the New Zealand Government's Climate Change Policies}

The New Zealand Government ratified the Kyoto Protocol in December 2002, taking responsibility for any excess in Greenhouse Gas emissions above the 1990 level for the period 2008-2012 (MfE, 2014). The Labour-led Government developed and revised different policy packages between 2002 and 2008 in order to reduce emissions. In April 2002, the Government announced its preference for a carbon tax (Hodgson, 2005). However, following a report examining implementation issues and consequences, the idea of a carbon tax was abandoned (Parker, 2005). In October 2007, the Government announced the Emissions Trading Scheme (NZ ETS). The NZ ETS was to be implemented on a nation-wide level, including all sectors and all gases (Parker, 2008). The Climate Change Bill, which outlines the operational mechanisms of the ETS and the moratorium on new thermal generation, became the Climate Change Act in September 2008.

In 2008, the newly elected National-led government reviewed the ETS and passed the ETS Amendment Act in June 2009, which allowed a number of concessions for industry participants during a transitional period through December 2012 (MfE, 2009). These transitional measures have since been extended beyond 2012 .

\subsection{Risks and Uncertainties associated with Climate Change Policies}

ETS-related regulations increase emitting organisations' risk exposure. An ETS internalises an environmental externality into organisation's cost structure through putting a price on emissions, therefore encouraging organisations to reduce emissions (Engels, 2009; Hopwood et al., 2010). There are also new compliance costs related to the measurement, monitoring and reporting of emissions and surrendering of carbon credits (Deloitte, 2007; Reinaud, 2005), as well as indirect energy cost increases, with high-energy users being more exposed (Lund, 2007; Reinaud, 2005). These costs in turn affect production costs and change industry and company's relative competitiveness, with energy-intensive industries and companies having to assess their ability to pass on additional costs, and potentially losing competitive advantage (CERES, 2007; Kolk \& Levy, 2001; Reinaud, 2005). The liabilities associated with future ETS compliance costs can influence the value of companies (Chapple et al., 2013). 
Deloitte (2007) highlights that 'companies making capital investment decisions face major strategic risks associated with technology availability and carbon pricing. There is technological risk due to the lack of available technology to mitigate carbon emissions and related costs that emanate from fossil fuel-based electricity generation. Market risk is associated with fluctuations in carbon prices and the differential ability of companies to pass carbon costs to consumers (Deloitte, 2007). Similarly, Bebbington and Larrinaga-Gonzalez (2008) suggest that price volatilities of carbon credit markets make it difficult to estimate compliance costs and add further pressure on organisational performance and risk management. These risks are present even after it is known with certainty that $\mathrm{CC}$ policies/regulations will be introduced.

CC also carries reputation risk for organisations (CERES, 2007). PWC's (2009) report on the Carbon Disclosure Project found that utility companies recognised their exposure to additional regulation and public scrutiny around emissions, especially with media and politicians' involvement. Increased societal awareness of CC has reinforced and accelerated the move to green consumerism, including a preference for low-carbon products and technologies (Elkington, 2004; Ottman, 1992). These trends increase reputational risks. We term these different types of risks $\mathrm{CC}$ risk.

These risks can also provide strategic market opportunities with companies developing green products to capitalise on green consumerism (Burritt et al., 2011; Hart, 1995). One company's risk can be another company's opportunity, e.g., compliance costs could be a risk for high emission companies, but present opportunities for low emission companies, enabling them to offer cheaper products/services.

In addition to the above $\mathrm{CC}$ risks (and opportunities), companies can also be exposed to regulatory uncertainty when international pressure builds, but the government does not signal its intended $\mathrm{CC}$ policies. This uncertainty can cause significant difficulty for companies to choose an appropriate strategic response as they cannot predict the likelihood nor the consequences of regulations. When $\mathrm{CC}$ regulations are certain, companies can estimate their compliance costs, under different scenarios, such as different carbon prices, or the presence or absence of carbon mitigation technology. Based on such estimates, they can formulate a strategic response, such as investing in renewable technologies. However, without regulatory certainty, companies can only await developments.

\section{THEORETICAL FRAMEWORK}

To understand how organisations can adopt strategies and carbon accounting practices to respond to $\mathrm{CC}$ risk, we develop a contingency-based theoretical framework. Contingency theory assumes that management accounting is designed to achieve predetermined purposeful organisational objectives (Chenhall, 2006; Malmi \& Brown, 2008), whilst being influenced by the organisational and external context within which they operate (Chenhall, 2003). Environmental uncertainty is generally found to be associated with more open, externally-oriented and non-financial information and more reliance on flexible and interpersonal forms of management accounting (Chenhall, 2003). Under conditions of high uncertainty accounting information plays a planning role which requires the involvement and interaction between different levels of management and timely information from the external environment to enable effective change (Chapman, 1998). Additionally, when budgetary controls are used in 
conditions of high environmental uncertainty, these controls are used in combination with frequent interaction between managers and staff, and the discussion of the causes of variances (Ezzamel, 1990; Merchant, 1990). Under highly competitive conditions, formal management accounting mechanisms, such as budgets and measures that capture continuous improvement, are favoured (Chenhall, 2003). After survival is ensured and performance is restored, organisations tend to move towards less formal management accounting mechanisms. Brownell (1985) finds that environmental complexity derived from suppliers and customers are associated with less emphasis on budgets. However, little is known about the role of management accounting under conditions with conflicting pressures from the environment. Management accounting that embodies interactive control systems can enable the co-existence of formal management accounting mechanisms with open, informal, and flexible information. Mundy (2010) found that using management accounting information as the basis for discussion between various levels of management within an organisation helps managers achieve a balance between controlling and enabling uses of management accounting. However, whether the use of this type of management accounting is more prevalent in conditions of high environmental complexity remains unknown. Sandelin (2008) considers operational complexity and found that high operational complexity requires the processing of greater amounts of information, and more formal forms of management accounting.

Rather than examining uncertainty and complexity as a general characteristic of the external environment, Chenhall (2003) suggests that specific element of the environment, such as social pressures on environmental responsibility, should be examined. Accordingly, our study focuses on one element of the environment, namely $\mathrm{CC}$ regulations and the risks derived from them. We provide a different way to view the external environment, that is, the level of risk (and opportunities) emanating from the environment. As the risk exposure of an organisation changes, appropriate strategies and management accounting have to be adopted to manage the changing risks effectively, whilst still achieving organisational objectives.

\subsection{Changes in Climate change Exposure}

Global carbon-related factors, including overseas CC policies, consumer preference, and public opinion, play an important role in business risk. Overseas CC policies the prospect of international agreements (EU) and the design of the Australian ETS can influence New Zealand Government policies. This was the case with the review of the original ETS in which the Government sought to align NZ ETS with EU/Australian ETS and modify it to incorporate the uncertainty of post-Kyoto arrangements. Changing consumer preference towards green and clean/low-carbon products is one of the key risk drivers for export businesses because failing to take action to mitigate emissions can threaten their competitiveness. Overall, these factors are likely to shape government policies and drive business $\mathrm{CC}$ risk exposure. Figure 1 reflects the relationships between these external factors, government policies, and business risk exposure. 


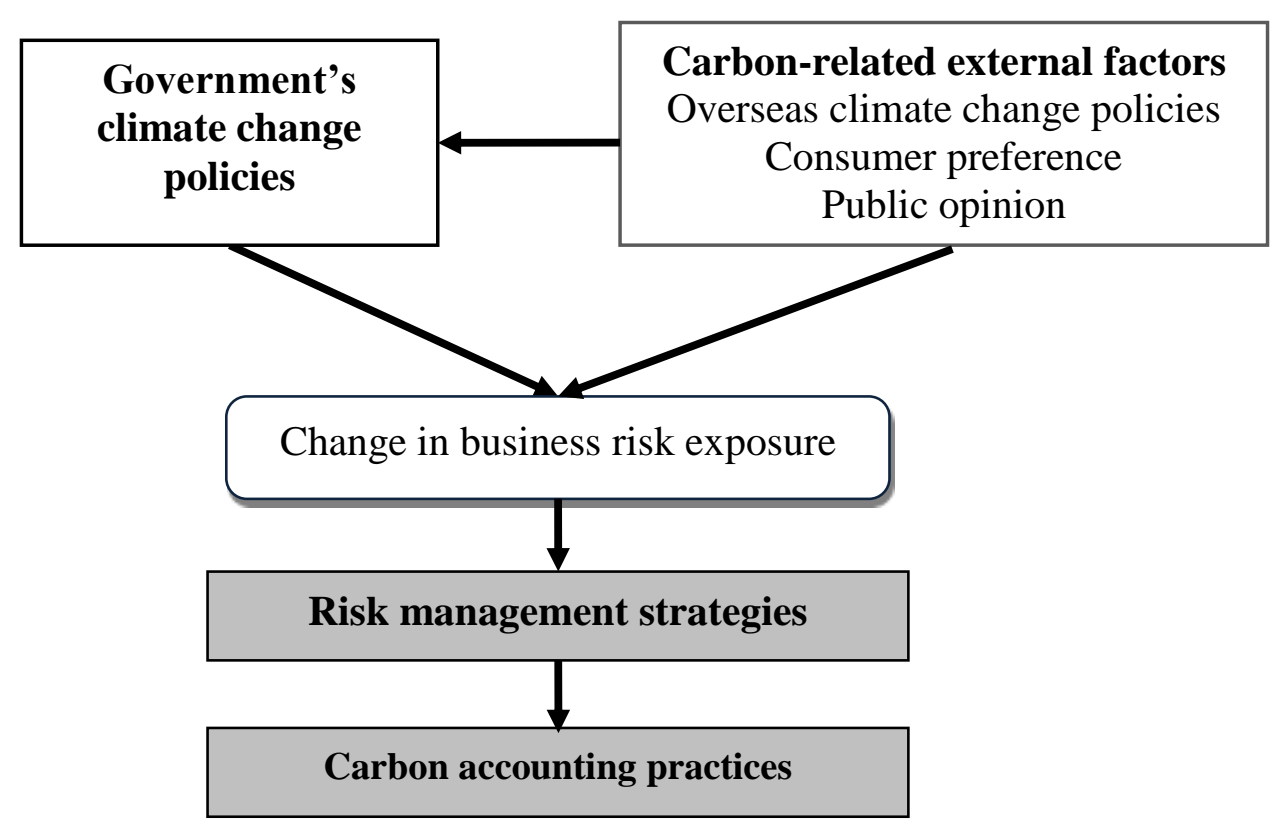

Figure 1: External risk drivers and risk management strategy research framework

\subsection{Strategies to Respond to Environmental Issues and Regulation}

In response to the risks and opportunities related to the ETS, businesses have to adopt effective management strategies. Much of the prior literature categorises environmental-related response strategies along a continuum from reactive to proactive strategies, dealing with issues of CC risks and market opportunities. These categorisations differ both in terms of their detail, and the organisational and external factors taken into account. We take a risk perspective to highlight the differences and similarities between the studies that provide unique stage-model typologies of environmental strategies, as discussed below and summarised in Table 1. We ignore studies that re-use previously published models and that do not examine CC or at least environmental risks/opportunities. A matrix is set up in which specific mixtures of CC risks and market opportunities are matched against different environmental strategies suggested by prior studies. Additionally, these strategies are represented by two common attributes: strategic orientation (internally versus externally-oriented) and activity/functional focus.

Table 1 shows substantial overlap between models, but also differences in the depth and scope of risks/opportunities considered, and the range of organisational functions covered. Some studies focus on environmental risks (Hunt \& Auster, 1990), on opportunities (Hart, 1995), or consider both (Jansson et al., 2000; Sharma, 2000; Steger, 1993). Some studies focus on organisational resource capability in determining organisations' response (Dutton \& Duncan, 1987; Hart, 1995), while others elaborate on the functions and activities undertaken for different environmental strategies (Azzone \& Bertelè, 1994; Russo \& Fouts, 1997).

We integrate these models of organisational environmental strategies with a specific focus on risk. Thus the link between risk, perception of risk, and corresponding choice of environmental strategy emerges. For example, where risks and opportunities are perceived to be low, resistance or no action are appropriate strategies. However, 
where $\mathrm{CC}$ risks are high, for example, in high-emitting industries, but low market opportunities, that is, consumers do not value green products, companies limit their efforts to compliance (Dutton \& Duncan, 1987; Hunt \& Auster, 1990), whilst monitoring policy developments (Azzone \& Bertele, 1994). Where CC risks are low, but market opportunities large, that is, low-emitting sectors where consumers prefer green products, an offensive strategy focused on green product development is more suitable (Hart, 1995; Hunt \& Auster, 1990; Steger, 1993). Finally, in sectors with high $\mathrm{CC}$ risks and major market opportunities, companies tend to pursue a proactive strategy, greening product and production processes, and seeking technological breakthrough (Azzone \& Bertele, 1994). Simultaneously, companies lobby government and participate in the regulatory process to enhance their prospects (Oliver, 1991). However, a common limitation of these studies is they only categorise environmental risks and market opportunities along the high/low dimensions. It is unclear what strategic responses are appropriate when environmental risks and/or market opportunities are potential, or of a moderate level, as shown in Table 1. Furthermore, these studies do not clearly identify appropriate activities suitable for each strategy.

Kolk and Pinkse (2005) examine 136 Global 500 companies and find they use different strategies to respond, namely to improve business activities through either innovation or compensatory measures internally, in cooperation with supply chain partners, or beyond their supply chain (e.g. NGOs or government). Jones (2007) studies North American companies' CC responses using three dimensions: ratings by external organisations, their commitments regarding emissions reductions (e.g. participating in voluntary emissions trading schemes), and joint political action. They find that the multiple corporate activities yield few tangible results. Further, the thoroughness of the response strategies depend on organisational exposure to climate risks, location, company capabilities, and top management preferences. Weinhofer and Hoffman (2010) examine a world-wide sample of electricity producers, reporting three strategies: carbon compensation (e.g. investing in carbon offset activities, participating in emissions trading scheme), carbon reduction (i.e. lowering carbon content in products and production), and carbon independence (designing carbon-free production and products). These strategies are often combined, and differ according to region, company size, and emission levels. Boiral (2006) suggests that a proactive strategy enables organisations to maintain social legitimacy, cope with external pressures, and achieve competitive advantage, because of new CC-related entry barriers. Disclosure and reporting of risks and strategies form an integral part of a proactive strategy (Atkins et al., 2015; Atkins \& Maroun, 2015; Stent \& Dowler, 2015). However, organisations may be reluctant to be proactive in the presence of regulatory uncertainty. 
Table 1: Summary of prior studies on Choice of Environmental strategy based on different mixes of environmental risks and market opportunities

\begin{tabular}{|c|c|c|c|c|c|c|c|c|c|c|}
\hline \multirow[t]{6}{*}{ Papers } & & \multicolumn{9}{|c|}{ Climate change risks/ Market Opportunities } \\
\hline & $\begin{array}{l}\text { Market } \\
\text { opportunities }\end{array}$ & Low & Low & Low & Moderate & Moderate & Moderate & High & High & High \\
\hline & Environmental risk & Low & Moderate & High & Low & Moderate & High & Low & Moderate & High \\
\hline & $\begin{array}{l}\text { Strategic } \\
\text { orientation }\end{array}$ & Internal & Internal & Internal + External & External & $\begin{array}{l}\text { Internal + } \\
\text { External }\end{array}$ & External & External & $\begin{array}{l}\text { External + } \\
\text { Internal }\end{array}$ & External \\
\hline & $\begin{array}{l}\text { Activity/ } \\
\text { functional focus }\end{array}$ & Production & $\begin{array}{l}\text { Production } \\
\text { Policy } \\
\text { oversight }\end{array}$ & $\begin{array}{l}\text { Production } \\
\text { Lobbying }\end{array}$ & Lobbying & $\begin{array}{l}\text { Production } \\
\text { Lobbying }\end{array}$ & $\begin{array}{l}\text { Lobbying } \\
\text { Legitimacy } \\
\text { management } \\
\text { R\&D }\end{array}$ & $\begin{array}{l}\text { Product } \\
\text { design Sales } \\
\& \text { Marketing }\end{array}$ & $\begin{array}{l}\text { Product design } \\
\text { Sales \& } \\
\text { Marketing } \\
\text { Lobbying } \\
\text { Production } \\
\end{array}$ & $\begin{array}{l}\text { R\&D } \\
\text { (technology } \\
\text { search) }\end{array}$ \\
\hline & Factors considered & \multicolumn{9}{|c|}{ Choice of Environmental strategy } \\
\hline Steger (1993) & $\begin{array}{l}\text { Market opportunities, } \\
\text { Climate change risks }\end{array}$ & Indifferent & & Defensive & & Defensive & & Offensive & & Innovative \\
\hline $\begin{array}{l}\text { Dutton and } \\
\text { Duncan (1987) }\end{array}$ & $\begin{array}{l}\text { Issue urgency } \\
\text { Capability to resolve }\end{array}$ & $\begin{array}{l}\text { No } \\
\text { response }\end{array}$ & & Resistance & & & & Opportunistic & & $\begin{array}{l}\text { Strategic } \\
\text { change }\end{array}$ \\
\hline $\begin{array}{l}\text { Hunt and Auster } \\
\text { (1990) }\end{array}$ & $\begin{array}{l}\text { Environmental risks } \\
\text { Impact on } \\
\text { environmental protection }\end{array}$ & $\begin{array}{l}\text { Fire fighter } \\
\text { Beginner }\end{array}$ & \multicolumn{2}{|c|}{ Concerned citizen } & & & & Pragmatist & Pragmatist & Proactivist \\
\hline $\begin{array}{l}\text { Azzone and } \\
\text { Bertele (1994) }\end{array}$ & $\begin{array}{l}\text { Issue importance and } \\
\text { activity focus }\end{array}$ & Stable & Reactive & Anticipatory & Anticipatory & Anticipatory & $\begin{array}{l}\text { Anticipatory/ } \\
\text { Creative }\end{array}$ & Proactive & Proactive & Creative \\
\hline $\begin{array}{l}\text { Russo and Fouts } \\
\text { (1997) }\end{array}$ & $\begin{array}{l}\text { Organisational } \\
\text { capabilities }\end{array}$ & & Compliance & Compliance & & & & Proactive & Proactive & Proactive \\
\hline $\begin{array}{l}\text { Rugman and } \\
\text { Verbeke (1998) }\end{array}$ & $\begin{array}{l}\text { Environmental-related } \\
\text { market opportunities } \\
\text { Management style } \\
\end{array}$ & & Compliance & Defy/Resist & & & & Opportunistic & Opportunistic & $\begin{array}{l}\text { Strategic } \\
\text { change }\end{array}$ \\
\hline Hart $(1995)^{2}$ & $\begin{array}{l}\text { Environmental } \\
\text { strategies that create } \\
\text { competitive advantage }\end{array}$ & & & Pollution prevention & & $\begin{array}{l}\text { Pollution } \\
\text { prevention }\end{array}$ & & $\begin{array}{l}\text { Product } \\
\text { stewardship }\end{array}$ & $\begin{array}{l}\text { Product } \\
\text { stewardship }\end{array}$ & $\begin{array}{l}\text { Sustainable } \\
\text { Developme } \\
\text { nt }\end{array}$ \\
\hline $\begin{array}{l}\text { Stead and Stead } \\
(2008)\end{array}$ & $\begin{array}{l}\text { Sustainable strategic } \\
\text { management }\end{array}$ & $\begin{array}{l}\text { Eco- } \\
\text { efficiency }\end{array}$ & & $\begin{array}{l}\text { Pollution prevention } \\
\text { Eco-efficiency }\end{array}$ & & $\begin{array}{l}\text { Pollution } \\
\text { prevention }\end{array}$ & & $\begin{array}{l}\text { Product } \\
\text { stewardship }\end{array}$ & $\begin{array}{l}\text { Product } \\
\text { stewardship }\end{array}$ & $\begin{array}{l}\text { Generative/ } \\
\text { creative }\end{array}$ \\
\hline $\begin{array}{l}\text { Jansson, Nilsson } \\
\text { and Rapp (2000) }\end{array}$ & $\begin{array}{l}\text { Environmental risks } \\
\text { and market opportunities }\end{array}$ & & & Reactive & & Active & Active & Proactive & & Proactive \\
\hline Sharma (2000) & $\begin{array}{l}\text { Environmental-related } \\
\text { market opportunities }\end{array}$ & & Compliance & Compliance & & & Compliance & Voluntary & & Voluntary \\
\hline $\begin{array}{l}\text { Weinhofer and } \\
\text { Hoffmann } \\
\text { (2010) }\end{array}$ & $\begin{array}{l}\text { Organisational size and } \\
\text { total emissions level }\end{array}$ & & $\begin{array}{l}\text { Carbon } \\
\text { compensation }\end{array}$ & $\begin{array}{l}\text { Carbon reduction } \\
\text { (in production) }\end{array}$ & & & & $\begin{array}{l}\text { Carbon indepe } \\
\text { (carbon-free } \mathrm{p} \\
\text { technological }\end{array}$ & $\begin{array}{l}\text { dence } \\
\text { duct design and } \\
\text { arch) }\end{array}$ & \\
\hline
\end{tabular}

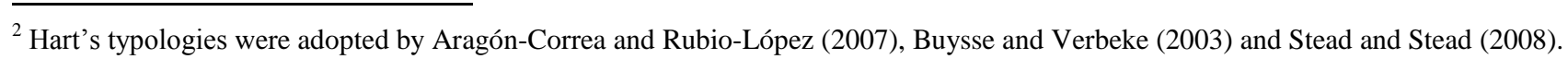


While the prior literature is consistent with our contingency theory framework, there is limited empirical evidence, especially around companies operating in the electricity generating industry. We develop a risk-based framework of CC strategies from the prior literature (Table 2). This framework encompasses both reactive and proactive strategies; considers production, product-design, and other organisational functions (e.g. public relations, research and development, accounting and finance functions).

Table 2: Climate change risks and opportunities mapped to Strategies

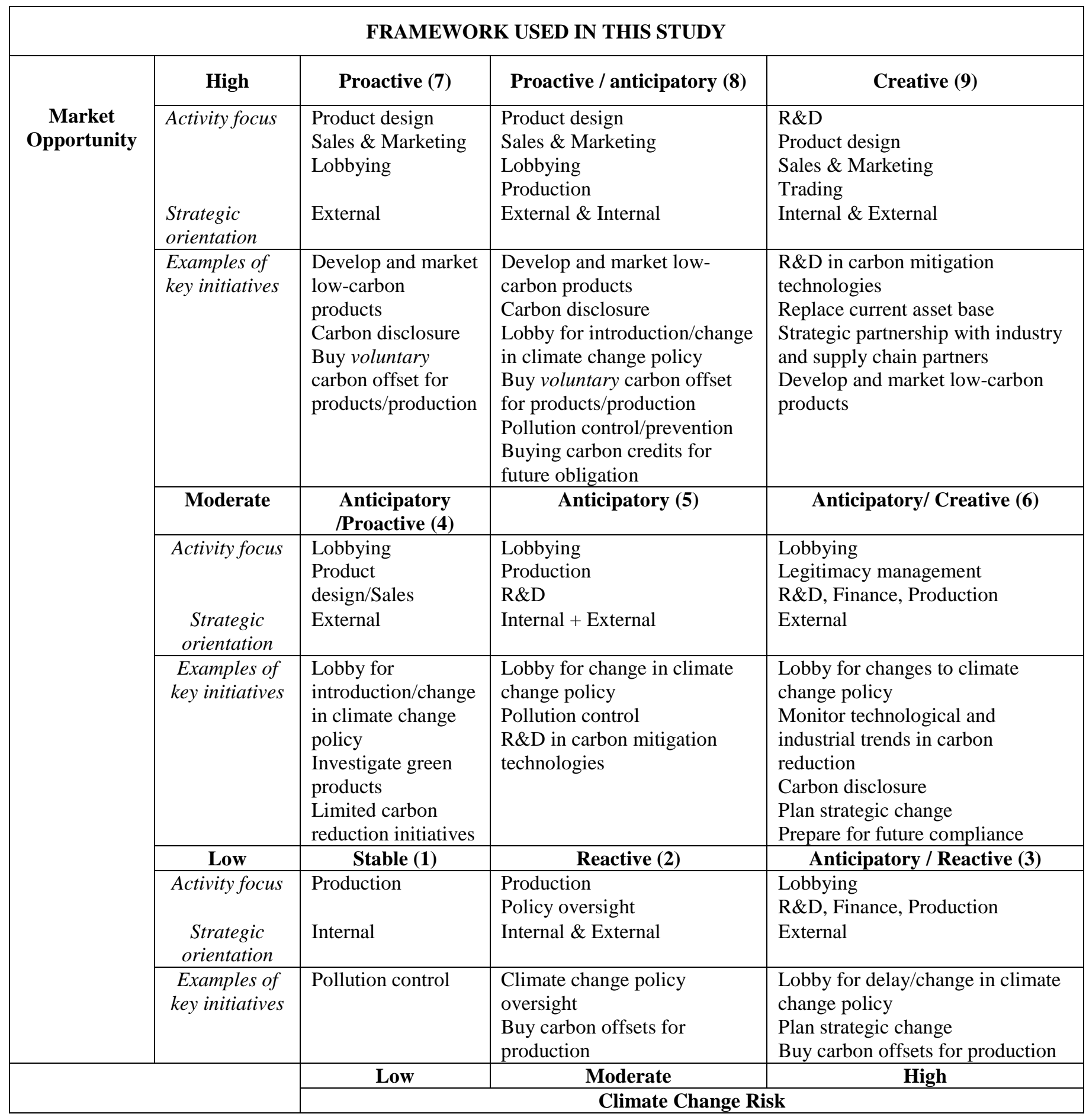


The range of strategies considered is not limited to pollution control and product stewardship (Hart, 1995), but also exploratory research projects of new technologies and lobbying strategies. We use Azzone and Bertele's (1994) strategic categories and names, because of the advantages that 1) they link contingencies and strategy, and 2) they include a 'potentially strategic' category. Their strategies are, in many ways, comparable with the typologies of other studies - see Table 1. However, we redefine these categories to ensure that we make use of the latest insights provided in all of the subsequent literature.

Our framework further extends the typologies in the prior literature by describing low, moderate, and high levels of $\mathrm{CC}$ risk and market opportunity (as opposed to the simple high/low classification typically found in the prior literature). We also highlight the activity focus, strategic orientation, and key initiatives of each strategic response. This helps establish the theoretical link between the strategic response that fit carbon accounting systems in terms of scope (broad/narrow), orientation (internal/external), and operational focus (Langfield-Smith, 2005; Sandelin, 2008). Our framework also integrates the literature on environmental management with more recent studies on $\mathrm{CC}$ issues. The strategies are:

- Stable strategy: This strategy is adopted when CC risks and opportunities are perceived to be low (box 1 in Table 2). Carbon management accounting is internally focussed in the functional areas of production and logistics. Companies gain cost savings through environmental efficiency (Hart, 1995; Stead \& Stead, 2008). Environmental initiatives are ad hoc and receive little management attention at both the operational and the strategic level.

- Reactive strategy: Environmental problems are not seen as strategic, but require policy monitoring by the legal and external relations functional areas. Pollution control within production remains important. This strategy is suitable when $\mathrm{CC}$ risks are perceived to be moderate or high, with little or no market opportunities (boxes 2 and 3). This strategy results in limited environmental protection, consistent with Hunt and Auster's (1990) concerned citizen strategy, and the compliance focus of Russo \& Fouts (1997) and Rugman \& Verbeke (1998). Companies often do not reduce emissions themselves, preferring to buy permits to meet their obligation, without substantially changing their production processes/technologies (Weinhofer \& Hoffmann, 2010). These carbon offsets only cover their production processes, without extending to other functional areas or product lifecycle stages.

- Anticipatory strategy: CC issues can become a strategic advantage or disadvantage. When companies perceive a moderate to high level of market opportunity and/or CC risk (boxes 3, 4, 5, 6 and 8), rather than waiting for policy to be imposed, companies participate in policy processes. Companies that identify opportunities (box 4) lobby for early introduction of policies to enable them to take advantage. In contrast, companies that identify risks (box 3 ) are likely to favour delays and changes to policy (the defy/resist strategy in Rugman and Verbeke (1998)). Companies exposed to moderate CC risk such as those in resource-based industries (boxes 5 and 8) also need to control their production-related emissions levels and prepare for future obligations by updating emissions monitoring, and buying carbon credits (Hart, 1995; Stead and Stead, 2008). Companies perceiving high risk and moderate opportunities 
(box 6) cannot stop at pollution control and lobbying. As carbon issues become critical to long term survival, cooperation between R\&D, Finance, and Production is needed to analyse the evolution of industry norms and plan appropriate strategic change (Azzone \& Bertele, 1994). Companies also increase carbon disclosure to respond to public and investor pressures associated with their emissions profile (Griffin et al., 2012; Reid \& Toffel, 2009). They may also prepare for regulatory compliance by implementing carbon monitoring systems or buying/holding carbon credits.

- Proactive strategy: Companies see many market opportunities (boxes 7 and 8), therefore marketing identifies consumer needs to drive product innovation. This is similar to an opportunistic or product stewardship environmental strategy (Rugman \& Verbeke, 1998; Stead \& Stead, 2008), or the pragmatist approach (Hunt and Auster, 1990). It also captures a carbon reduction focus where companies seek to lower carbon content in their products (Weinhofer \& Hoffmann, 2010). Companies are also likely to buy voluntary carbon offsets for their products/services that extend beyond production processes (Lovell et al., 2009; Scipioni et al., 2012). Lobbying remains important as companies seek to maximise their gains from carbon-related policies. Companies that also perceive moderate $\mathrm{CC}$ risk (box 8) will also need to focus on internal pollution control/prevention initiatives to manage carbon costs and legitimacy risk. Emissions from production is reduced through innovation (Kolk \& Pinkse, 2005; Weinhofer \& Hoffmann, 2010). Companies adopt carbon accounting for market reasons instead of merely reacting to legislation (Sharma, 2000). A limited form of proactive strategy may be adopted when companies perceive potential market opportunities and low risk (box 4).

- Creative strategy: Carbon management becomes critical for long term survival as companies perceive high levels of risk and opportunities associated with CC policy (box 9). Monitoring is required and potentially investment in carbon mitigation technologies and replacement of the current asset base. This implies senior management commitment, cross-functional collaboration, and major accounting impacts. Involvement from external stakeholders such as industry and supply chain partners is also likely (Azzone and Bertele, 1994). Companies also develop and market green products and participate in the emerging carbon market. An integrated approach across functions is needed (Rugman and Verbeke, 1998) to move towards sustainability (Hart, 1995). This is consistent with an independence-focused CC strategy (Weinhofer \& Hoffmann, 2010).

\subsection{Carbon Management Accounting (CMA)}

These changes in CC-related risk exposure and organisations' risk management strategies hold important implications for accounting practice, i.e. the collection, summarisation and measurement of emissions data, in both monetary and physical terms (Stechemesser \& Guenther, 2012; Tang \& Luo, 2014). Monetarised data can include costs, liabilities, revenue from selling carbon credits, and estimated cost savings from new investments. Schaltegger and Csutora (2012) classify CMA into corporate accounts for sustainability (e.g. investment/spending in carbon reduction initiatives, carbon reductions due to new investment, or the resultant cost reductions), and accounts for unsustainability (e.g. emissions levels or emissions intensity). 
CMA has four key uses, namely to monitor compliance, to motivate continuous improvement, to provide data for internal decision-making, and to provide data for external reporting (Henri \& Journeault, 2010). Collected data can be compared, reviewed, improved, and benchmarked (Tang \& Luo 2014). CMA can also be used in voluntary carbon reduction programmes (Burritt et al. 2011) and allows information to be used in operational and strategic decision-making across organisational functions, including business policy, human resource management, marketing, supply chain management, and finance strategies and performance evaluation (Derchi et al., 2013; Ratnatunga \& Balachandran, 2009). CMA also includes calculating carbon footprints (Stein \& Khare, 2009), calculating 'whole-of-life' costs of products/services (Scipioni et al., 2012; Tsai et al., 2012), and measuring supply chain sustainability (Burritt \& Schaltegger, 2014).

Nevertheless, little is known about the processes, and strategic drivers of CMA (Jeswani et al., 2008). Gond et al. (2012), Arjaliès and Mundy (2013), and Burritt et al. (2011) all contribute, but none of these studies specifically examine how changes in strategy map to changes in the management accounting systems used. In addition, these studies do not address the explicit relationship between accounting and CC risks and opportunities in a longitudinal manner. In other words, the implications of a change in CC risks, as perceived by an organisation, for its accounting practice have been under-explored. Furthermore, little is known about the link between risk management strategies and accounting practices.

Hence this study examines CMA along the following dimensions: types of accounts (sustainability/unsustainability) (Schaltegger and Csutora 2012), key carbon indicators (Stein \& Khare, 2009), the design of carbon accounts (physical or monetary) (Stechemesser \& Guenther, 2012), uses of carbon accounts to support decisions, and the existence and extent of carbon offsetting (Dhanda \& Hartman, 2011).

\section{METHOD}

\subsection{Research Subjects and Participants}

This study adopts a case study approach (Yin, 2003) to investigate potential changes in the environment-related risk management strategies of the five largest New Zealand electricity generators. The five generators also retail their electricity, and make up $91 \%$ and $95 \%$ of the New Zealand wholesale and retail electricity market share (2002 data). We choose electricity generators because, first, they are among the first to enter and experience the effects of the NZ ETS. Second, the risk impacts of the ETS on electricity generators are also the highest because, unlike the EU/Australian ETS, generators do not receive any financial assistance (i.e. carbon credit/allowance allocation) from the Government. Third, a key objective of the ETS is to use a change in electricity pricing to modify business behaviour (Reinaud, 2005; Hopwood, 2009).

Electricity generation accounted for $18.6 \%$ of energy-related emissions in New Zealand in 2002 (MBIE, 2013b). In 2002, 70\% of generation was from renewable sources, increasing to $77 \%$ in 2011 (MBIE, 2013a). The emissions intensity of generation went from 153 tonnes/Gwh in 2002 to 116 tonnes/Gwh in 2011 (MIBIE, 2013b), indicating significant changes. 
The different characteristics of the five companies in the study affect their CC risk exposure. The first two companies are thermal-based (called ThermalA and ThermalB), with $62 \%$ and $78 \%$ of their electricity generated from thermal sources respectively (coal, gas, and oil). The other three are renewable-based. RenewC and RenewD generate electricity exclusively from renewable sources (hydro and wind), while $90 \%$ of RenewE's production is from renewable sources (hydro and geothermal). ThermalA and RenewD are privately-owned while the remaining three are state-owned. The inclusion of these five generators ensures that the key players in the industry are covered, whilst heterogeneous organisational characteristics ensure differences in carbon-related risk management strategies and accounting practice.

\subsection{Data and Methods}

We interviewed electricity generators' senior managers, risk and emissions trading professionals, industry association and lobby groups, and electricity and CC government regulators. Fourteen interviews were conducted with directors/managers of the electricity generators, and 30 interviews with directors/managers of related organisations. The interviewed directors/managers often have more than four years of experience in their current positions, while the middle managers mostly have three to four years of experience. Half of the interviewees have an accounting background and/or direct responsibility for accounting-related functions. About a third of the interviewees from related organisations have some accounting background or expertise, while most of them are experts in CC regulations or industry specific issues. Table 3 provides more detailed information regarding generator interviewees, and Table 4 regarding related interviewees.

Table 3: Profile of interviewees in the generators and interview details

\begin{tabular}{|c|c|c|c|c|c|}
\hline No. & Generator & Role/Title & $\begin{array}{l}\text { Years in } \\
\text { current } \\
\text { position }\end{array}$ & $\begin{array}{c}\text { Date of } \\
\text { interview }\end{array}$ & $\begin{array}{c}\text { Length } \\
\text { of } \\
\text { interview }\end{array}$ \\
\hline 1 & \multirow[t]{2}{*}{ ThermalA } & Chief Financial Officer & 5 & $1 / 09 / 2009$ & $60 \mathrm{~min}$. \\
\hline 2 & & Carbon and Trading Manager & 10 & $10 / 08 / 2009$ & $90 \mathrm{~min}$. \\
\hline 3 & \multirow[t]{2}{*}{ ThermalB } & Director who is a chartered accountant & 4 & $16 / 09 / 2009$ & $50 \mathrm{~min}$. \\
\hline 4 & & Carbon Trading Manager & 3 & $17 / 09 / 2009$ & 65 min. \\
\hline 5 & \multirow[t]{6}{*}{ RenewC } & Director with accounting background & 5 & $2 / 09 / 2009$ & $80 \mathrm{~min}$. \\
\hline 6 & & Generation Managing Director & 6 & $3 / 09 / 2009$ & $55 \mathrm{~min}$. \\
\hline 7 & & Accountant in charge of carbon inventory & 3 & $11 / 09 / 2009$ & $68 \mathrm{~min}$. \\
\hline 8 & & Financial controller & 3 & $11 / 09 / 2009$ & $50 \mathrm{~min}$. \\
\hline 9 & & Climate Change Manager & 4 & $20 / 09 / 2009$ & $90 \mathrm{~min}$. \\
\hline 10 & & $\begin{array}{l}\text { Communications and External Relations } \\
\text { Manager }\end{array}$ & 7 & $20 / 09 / 2009$ & $72 \mathrm{~min}$. \\
\hline 11 & \multirow[t]{2}{*}{ RenewD } & Chief Financial Officer & 4 & $21 / 09 / 2009$ & $60 \mathrm{~min}$. \\
\hline 12 & & Carbon and Trading Manager & 3 & $22 / 09 / 2009$ & $70 \mathrm{~min}$. \\
\hline 13 & \multirow[t]{2}{*}{ RenewE } & Senior Accountant & 5 & $2 / 10 / 2009$ & $63 \mathrm{~min}$. \\
\hline 14 & & Carbon and Climate Change Manager & 3 & $8 / 10 / 2009$ & $75 \min$. \\
\hline
\end{tabular}


Table 4: Profile of interviewees in external organisations and interview details

\begin{tabular}{|c|c|c|c|c|c|}
\hline No. & Organisation & Role/Title & $\begin{array}{l}\text { Years } \\
\text { in } \\
\text { current } \\
\text { position }\end{array}$ & $\begin{array}{l}\text { Date of } \\
\text { interview }\end{array}$ & $\begin{array}{l}\text { Length } \\
\text { of } \\
\text { interview }\end{array}$ \\
\hline 1 & Accounting firm 1 & $\begin{array}{l}\text { Leader, Sustainability } \\
\text { Services }\end{array}$ & 8 & $3 / 9 / 2009$ & $60 \mathrm{~min}$. \\
\hline 2 & & Partner & 12 & $5 / 10 / 2009$ & 45 min. \\
\hline 3 & Accounting firm 2 & $\begin{array}{l}\text { Director, Sustainability and } \\
\text { Climate Change team }\end{array}$ & 6 & $21 / 9 / 2009$ & 90 min. \\
\hline 4 & Accounting firm 3 & Senior Manager, Audit & 4 & $17 / 9 / 2009$ & $60 \mathrm{~min}$. \\
\hline 5 & & $\begin{array}{l}\text { Director, Climate Change } \\
\text { and Sustainability }\end{array}$ & 4 & $17 / 9 / 2009$ & $75 \mathrm{~min}$. \\
\hline 6 & Accounting firm 4 & $\begin{array}{l}\text { Senior Manager, } \\
\text { Sustainability Services }\end{array}$ & 8 & $8 / 10 / 2009$ & 90 min. \\
\hline 7 & & Partner & 5 & $3 / 11 / 2009$ & 50 min. \\
\hline 8 & Professional body & $\begin{array}{l}\text { Director, Accounting } \\
\text { standards } \\
\text { Manager, Accounting } \\
\text { Standards }\end{array}$ & 6 and 4 & $26 / 10 / 2009$ & $80 \mathrm{~min}$. \\
\hline 9 & Research institute 1 & Senior Research Fellow & 4 & $9 / 9 / 2009$ & 60 min. \\
\hline 10 & & Research Fellow & 7 & $7 / 10 / 2009$ & $80 \mathrm{~min}$. \\
\hline 11 & Research institute 2 & Senior Research Fellow & 4 & $20 / 10 / 2009$ & 48 min. \\
\hline 12 & Carbon trading firm 1 & Director & 4 & $11 / 9 / 2009$ & $60 \mathrm{~min}$. \\
\hline 13 & Carbon trading firm 2 & Chief Executive Officer & 3 & $12 / 9 / 2009$ & $60 \mathrm{~min}$. \\
\hline 14 & Carbon trading firm 3 & Manager & 5 & $16 / 11 / 2009$ & 60 min. \\
\hline 15 & Consulting firm 1 & $\begin{array}{l}\text { Director, Energy and the } \\
\text { Environment Group }\end{array}$ & 6 & $17 / 9 / 2009$ & 50 min. \\
\hline 16 & Lobby group 1 & Chief Executive Officer & 5 & $22 / 10 / 2009$ & 75 min. \\
\hline 17 & Lobby group 2 & Chief Executive Officer & 4 & $3 / 11 / 2009$ & 75 min. \\
\hline 18 & Lobby group 3 & Chief Executive Officer & 5 & $5 / 11 / 2009$ & 45 min. \\
\hline 19 & & Manager & 4 & $18 / 11 / 2009$ & 50 min. \\
\hline 20 & Regulator 1 & Manager, Climate Change & 6 & $9 / 11 / 2009$ & 50 min. \\
\hline 21 & Regulator 2 & $\begin{array}{l}\text { Manager and Senior } \\
\text { Adviser, Energy and the } \\
\text { Environment }\end{array}$ & 8 and 4 & $10 / 11 / 2009$ & $60 \mathrm{~min}$. \\
\hline 22 & Political party 1 & Senior Adviser & 8 & $28 / 10 / 2009$ & 90 min. \\
\hline 23 & Political party 2 & Member of parliament & 10 & $12 / 11 / 2009$ & 80 min. \\
\hline 24 & Political party 3 & Member of parliament & 9 & $16 / 11 / 2009$ & 45 min. \\
\hline 25 & Political party 4 & Senior adviser & 6 & $15 / 11 / 2009$ & 70 min. \\
\hline 26 & Newspaper 1 & Economic Editor & 12 & $5 / 11 / 2009$ & $90 \mathrm{~min}$. \\
\hline 28 & Law firm 1 & Partner and Manager & $\begin{array}{l}10 \text { and } \\
4\end{array}$ & $9 / 11 / 2009$ & 59 min. \\
\hline 29 & Environmental consultancy 1 & Specialist & 5 & $8 / 9 / 2009$ & $50 \mathrm{~min}$. \\
\hline 30 & Environmental consultancy 2 & Chief Executive Officer & 8 & $30 / 11 / 2009$ & 50 min. \\
\hline
\end{tabular}

The interviews were conducted in an informal manner and questions were designed to fit with the roles of interviewees (Warren, 2002). The questions were initially formulated based on the prior literature and then continuously updated during the 
process of data collection to reflect new understanding and insights gained from prior interviews. Appendix A lists the main semi-structured interview questions.

The study also uses a wide range of publicly available documents that relate to electricity generators' strategies and operations, including annual reports, environmental/sustainability reports (Massa et al., 2015), websites, press releases, their submissions to the Government policy consultation process, and media articles/reports about the generators from January 2000 to October 2009. These documents help validate claims from the interviewees. Submissions shed light on the lobbying activities of the generators, while government reports and media articles assist in identifying the pressures involved.

The following five periods correspond to major changes in government policies:

- Period 1: From 2000 to March 2002 before any CC policies were announced.

- Period 2: From April 2002 when the plan carbon tax was announced to December 2005 when the plan was cancelled.

- Period 3: From January 2006 to September 2007 when the ETS was under development and finally announced in September 2007.

- Period 4: From October 2007 until September 2008 when the Climate Change Act (2008) was passed that legislated the ETS.

- Period 5: From October 2008 to October 2009 when there was a change of government, the ETS was delayed and potentially exposed to substantial legislative changes.

Thematic coding and analytical tools are used to code and analyse the data, allowing for "rich and detailed, yet complex, accounts of data" (Braun \& Clarke, 2006, p. 78). Data from different sources are compared (Miller et al., 2004), reflecting data triangulation (Denzin, 2009; Flick, 2009). An interactive interview pattern is adopted to enable cross-validation of prior data (Covaleski \& Dirsmith, 1988). This helps reduce misunderstandings, while adding new insights and perspectives (Hoque et al., 2013; Modell, 2010).

\section{RESULTS}

\subsection{Changes in Climate Change Risk Exposure and Strategies over Time}

This section presents the changes in CC risk exposure and the strategies chosen by the five electricity generators.

\section{Period 1 - stable strategy}

Before 2002, CC was not seen as an important issue. There was no prospect of CC legislation, therefore there was no $\mathrm{CC}$ risk and no regulatory uncertainty.

Emissions reporting and management were required under the Resource Management Act 1992. Environmental management was a responsibility of the production function. A representative from a lobby group mentioned that "[c]arbon emissions were treated like any other environmental impact". Companies undertook operational efficiency and cost savings initiatives, which may have reduced emissions. 
Generators maintained their historical asset base and strategy. Thermal generators investigated potential thermal projects, while renewable generators considered both renewable and thermal projects. Pursuing $100 \%$ renewable generation was perceived as risky:

...management... was of the view that it isn't prudent to be $100 \%$ renewable... We had interests in co-generation and some fossil fuel based boilers... and... we would buy hedges based on non-renewable generated electricity. (Director, RenewC)

Consequently, no initiatives were undertaken to manage/reduce carbon emissions. This is consistent with the stable strategy shown in box 1 , Table 2, with low levels of risk and opportunities.

\section{Period 2 - anticipatory and proactive strategies}

With the government's ratification of the Kyoto protocol and the announcement of the carbon tax plan in April 2002, thermal electricity generators understood this would lead to emissions liabilities. However, since the carbon tax was not scheduled to be enforced until 2008, managing this risk was not seen as urgent. The generators recognised growing public awareness and increasing pressure to address environmental concerns and two renewable generators recognised an opportunity for green branding. They also recognised an opportunity to gain free carbon credits by starting approved renewable energy projects (PRE-projects). A manager from a regulator explained: "The idea of these projects was to help companies pursue renewable investments, which was not as cheap as coal or gas then. By giving companies free carbon credits, these projects would become more financially attractive." However, some uncertainty emerged as regulatory details were still lacking.

The generators recognised the possible strategic implications of these changes on their cost, profits and competitiveness, consistent with Khlif et al. (2015) and Maroun (2015), and most started to analyse CC risks and opportunities for planning and possible repositioning purposes. This is consistent with an anticipatory strategy. Four companies also received carbon credits equal to the amount of emissions saved by their PRE-projects. Additionally, all companies advised the Government in its development of a CC policy and New Zealand Energy Strategy (2002-2006). A lobby group manager reflected: "It was around the time of the carbon tax announcement that our group was formed... for the interest of emissions-intensive organisations." This group argued for changes/delays to reduce its members' carbon costs. The thermal generators tightened emissions controls and monitoring, and ThermalB began research into carbon capture technology. The preparation of thermal generators for a carbon-related compliance obligation is consistent with an anticipatory strategy (box 5, Table 2), with moderate levels of both opportunity and risk (due to high emissions).

Recognising rising public awareness of CC issues, two renewable generators started to measure/monitor their retail- and corporate-related emissions. They undertook some carbon reduction initiatives to further enhance their reputation. Their (minimal) emissions levels presented a market opportunity rather than a risk, as a manager from RenewD said: "Our emissions levels were very small compared to thermal generators. However, we need to reduce our non-generation emissions... We want to show that we care... consistent with our renewable asset base." The renewable 
generators' approach fits with the anticipatory/proactive strategy (box 4, Table 2), with moderate levels of opportunity and low levels of risk (due to low emissions).

\section{Period 3 - anticipatory, proactive, and creative strategies}

In December 2005, the government cancelled its plan for a carbon tax and investigated alternative policy options. Despite this, with the introduction of the ETS for electricity generation in the European Union and in some states of the United States, all the generators recognised that carbon issues would likely remain of strategic importance. However, they expressed concern over the uncertainty caused by the absence of a clear CC policy. Renewable generators perceived higher uncertainty (than thermal), because the lack of carbon pricing affected the economic viability of their existing and planned renewable investments. A manager of RenewD reflected: "Our renewable projects registered under the PRE scheme become questionable... not [being] quite sure when we can sell the granted carbon credits."

All the companies participated actively by lobbying and participating in the New Zealand Energy Strategy. A lobby group representative commented "Our group kept a close watch and participated actively... We held discussions with regulators and politicians... [S] ome big energy firms did the same”.

A wider range of departments now became involved in $\mathrm{CC}$ planning and risk assessment, in thermal generators focussing on potential liabilities and costs. They prioritised carbon reduction through optimising operational efficiency and substituting lower-emitting gas for higher-emitting coal fuels, and investigated carbon capture technology. Their actions are consistent with a combination of anticipatory and creative strategies (box 6, Table 2) (moderate opportunity, high risk).

Renewable-based generators foresaw a competitive advantage. "Many customers switch to us, because they see that as part of the solution" (Middle manager, RenewC). Renewable generators now decided that all future production, generation investment, and branding would be based on renewables.

What I and a number of colleagues said on the board is... the world has moved on. Individual companies have branded themselves effectively in this space, why would [we] not... we should move as much as possible into renewables... (Director, RenewC)

They also initiated some internal energy efficiency projects to reduce non-generation emissions. A manager from environmental consultancy 2 stated: "the public these days expect firms to manage and reduce their emissions... the public wants concrete actions". Now, these energy efficiency projects were not ad hoc as in Period 2, but were integrated into the CC plan with clear reduction targets. Marketing campaigns now focused on communicating a low-carbon image. RenewC adopted a carbon neutral programme. These actions were different from those of thermal generators and fit the proactive strategy in box 7, Table 2 (high opportunity, low risk).

\section{Period 4 - anticipatory, proactive and creative strategy}

With the announcement of the ETS in 2007, the generators recognised a number of common $\mathrm{CC}$ risks. The biggest risk was the change in fuel economics and impact on generation investment options.

"With carbon pricing, the economics of fuels is likely to change... We need to adjust our investment decisions to reflect this..." (Senior manager, ThermalA) 
"Carbon pricing will change the economies between alternative fuels... [and] the landscape of new generation investment..." (Manager, regulator 1)

The ETS was also perceived to impose substantial carbon liabilities on thermal generators, affecting profitability and competitiveness, as a senior manager from ThermalB explained:

"Carbon pricing will add additional cost to new thermal-based generation investment and there is no guarantee that wholesale prices will increase sufficiently to cover it... It is a huge business challenge."

A senior adviser (Regulator 2) said: "How big the carbon costs are depends on how carbon-intensive a business is. The more carbon-intensive, the... more financial pressure for them to switch to lower-carbon technology". Companies were also concerned about the fluctuations of carbon prices and the variations in carbon credit types and quality on the market. Although the ETS announcement ensured certainty on carbon pricing, many details remained uncertain.

A number of market opportunities were recognised. The ETS signalled a positive regulatory environment for renewable investments: "What the ETS really aims to change is the decisions made... there is a clear signal there should be no more coal, probably no more gas..., but go for geothermal, go for wind." (Journalist). Renewable generators were not exposed to any carbon costs and liabilities and would actually make "huge windfall gains" (Director, ThermalB).

The ETS now meant that thermal generators needed to develop carbon trading expertise, potentially representing a risk for renewable generators. A middle manager from RenewC explained: "due to their compliance obligations, thermal generators have substantial leverage to develop carbon trading expertise. They can potentially attract big emitter customers who want to deal with suppliers who sell electricity and carbon credits in one bundle."

In addition, all generators recognised an opportunity for energy efficient products/services due to $\mathrm{CC}$ awareness and consumers' desire to avoid higher electricity bills.

A wide range of strategies were undertaken to respond to these risks and opportunities. By 2007 most generators had developed CC action plans, including changes to generation investment plans. These plans all shifted towards renewables. Three companies announced substantial capital expenditure commitment to renewable projects (ThermalA, RenewC, RenewE). They not only depended on existing renewables (wind and hydro), but also investigated alternatives. This represents a carbon independence strategy (Weinhofer \& Hoffmann, 2010) or creative strategy (Azzone and Bertele, 1994) where companies moved to replace their asset base and pursue carbon-free production (box 9, Table 2).

Three generators achieved carbon neutrality certification. RenewC measured and offset emissions for the whole product lifecycle, while RenewE and ThermalA only offset for retail- and corporate functions-related emissions (as they still had generation-related emissions). Renewable generators branded themselves as 'cleanand-green'. All companies introduced energy efficiency initiatives internally and for customers. Four companies (excluding only RenewD) developed and marketed energy efficient products, such as smart meters and gas boilers, for customers. This represents a proactive strategy (box 8 , high opportunity, moderate risk). 
The thermal generators formulated carbon credit strategies and appointed dedicated carbon credit trading managers. One firm (ThermalB) pre-emptively bought large quantities of carbon credits offshore. The generators also lobbied for changes during the ETS public consultation period. These activities are consistent with an anticipatory strategy (box 6, moderate opportunity, high risk).

\section{Period 5 - reactive strategy}

The change of government in late 2008 led to the ETS being delayed and reviewed. While most of the risks and opportunities remained, the level of perceived risk was reduced. However, substantial uncertainties remained, including allocation of carbon credits, entry timetable of the energy sector, the point of compliance, and the requirements of carbon reporting, verification and surrendering. There was also uncertainty whether the NZ ETS would be aligned with the Australian ETS. A manager from accounting firm 1 explained that "[w]ith the price cap being introduced in Australia, it is likely that New Zealand will follow suit. That will substantially reduce the compliance costs, but we are not sure when that cap will be introduced, and for how long". High uncertainty "makes it really hard for firms to make their investment decisions... into renewable sources" (senior researcher, research institute 2).

Despite the ETS delay, investment decisions were still based on the long-term assumption that "carbon pricing and social preference for renewables would be a future reality" (Member of Parliament, political party 2). In fact, high-emissions company, ThermalB, decided to retire some thermal plants and accelerated its renewable energy development programme. A researcher (research institute 1) explained: "as the government decided not to compensate this firm for its loss under the ETS, they have no choice, but to retire these assets to avoid the high carbon costs caused by their emissions". However, the other four generators only progressed with projects already under way. Regulatory uncertainty significantly influenced carbon credit strategies, with ThermalA, ThermalB and ThermalC all deciding to stop buying carbon credits.

[Buying carbon credits and buying from whom] is something we thought about, and are thinking about, but before we can really do that, we need to know the exact structure that NZ and Australian schemes are. Because before we know that, we can't reach agreements. (Middle manager, ThermalA)

By the end of 2010, all the carbon neutrality programmes were discontinued in the renewable generators. Though renewable generators still pursued a green brand, they no longer 'considered carbon neutrality as essential to the green image'. With the ETS delayed, the generators reduced their lobbying activities and reverted to monitoring policy changes. This "wait and see" approach and the cancellation of creative/proactive carbon management initiatives is consistent with a reactive strategy (box 2, table 2).

Table 5 summarises the changes in risk exposure of the electricity generators, driven by the changes in external risks, including $\mathrm{CC}$ risks and opportunities and regulatory uncertainties. 
Table 5: Change in Risk exposure and Risk management strategy from 2002 to 2009

\begin{tabular}{|l|l|l|l|l|l|}
\hline & Period 1 & Period 2 & Period 3 & Period 4 & Period 5 \\
\hline $\begin{array}{l}\text { Climate change } \\
\text { risks }\end{array}$ & $\begin{array}{l}\text { Low } \\
\text { Compliance } \\
\text { risks }\end{array}$ & $\begin{array}{l}\text { Moderate (T), } \\
\text { Low (R) } \\
\text { Potentially } \\
\text { strategic }\end{array}$ & $\begin{array}{l}\text { High (T) } \\
\text { Strategic } \\
\text { Low (R) }\end{array}$ & $\begin{array}{l}\text { High (T) } \\
\text { Strategic } \\
\text { Medium (R) }\end{array}$ & $\begin{array}{l}\text { Medium } \\
\text { Strategic }\end{array}$ \\
\hline $\begin{array}{l}\text { Market } \\
\text { opportunities }\end{array}$ & Low & Medium (T+R) & $\begin{array}{l}\text { Moderate (T) } \\
\text { High (R) }\end{array}$ & High (T+R) & Medium \\
\hline $\begin{array}{l}\text { Climate change } \\
\text { risk exposure }\end{array}$ & \multicolumn{2}{|c|}{ Increasing } & Decreasing \\
\hline $\begin{array}{l}\text { Regulatory } \\
\text { uncertainties }\end{array}$ & Low & Medium & High & Medium & High \\
\hline
\end{tabular}

Note: T: Thermal generators; R: Renewable generators

In response to these changes in the degree and mixtures of risk exposure, electricity generators have changed their risk management strategies, as summarised in Table 6.

Table 6: Risk management strategies in response to climate change risk exposure

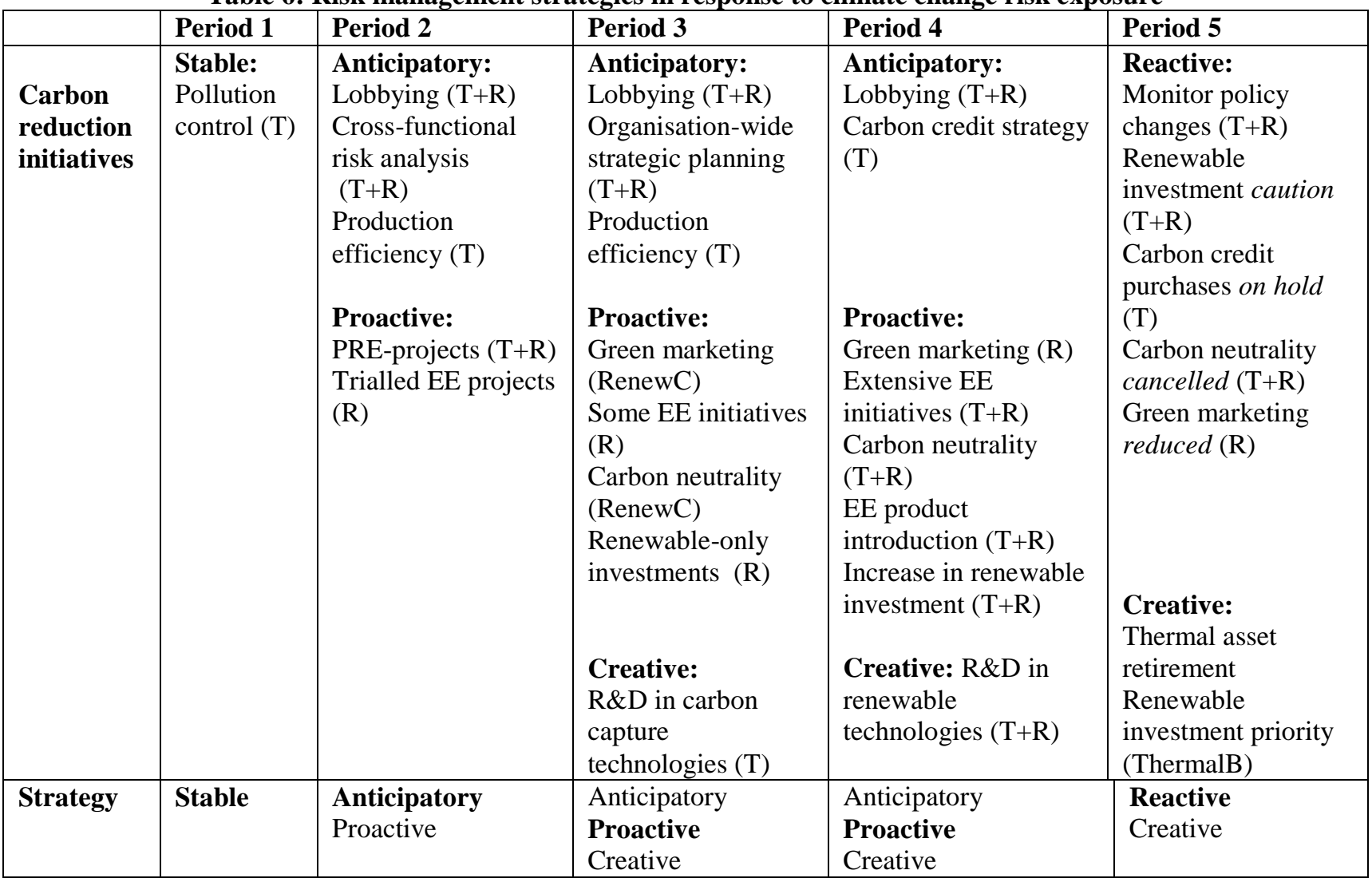

Note: T: Thermal generators; R: Renewable generators, EE: Energy efficiency

Table 6 shows companies becoming more proactive until period 4, before reverting to more reactive strategies. 


\subsection{Carbon management accounting (CMA) (design and use of carbon measures)}

Period 1. Prior to 2002, environmental issues bore only operational risks. Two thermal generators and RenewE (who had limited thermal generation) used CMA to monitor carbon emissions, but CMA was not integrated with anything else. This monitoring was limited to the emissions arising from generation. Monitoring was designed to satisfy minimum regulatory requirements. As the companies did not report emissions data externally, benchmarking was not really possible. The other two renewables generators, who did not have any generation-related emissions, did not measure/monitor emissions.

The data was historic, ad-hoc, and short-term in nature. The environmental manager of ThermalA said "Emissions data just sat there, nobody other than the environmental or production manager cared about them and they definitely did not get reported [to top management]". This type of CMA represents accounts for unsustainability (Burritt \& Schaltegger, 2012).

Period 2. CMA now started to play an active role in supporting companies' strategies. After the carbon tax announcement, the implications were addressed at the strategic level using emissions data.

Yes, emissions information was essential... we knew what our carbon exposure could be. No comparative information from competitors was available, but I am sure all the boards in other generators were [also]... measuring emissions (Senior manager, ThermalA)

Thermal generators used physical emissions measures to estimate the level of CC risk exposure, and to inform strategic planning. Carbon liabilities were estimated at the proposed \$25 per tonne. Thermal generators also started to improve their operational energy efficiency. Generation emissions information was audited and benchmarked:

The industry was quite supportive of... There was... a lot of the measuring and monitoring... [and] international benchmarking. A lot of money has been spent on that work. (A lobby group representative)

The limited proactive strategies undertaken were also supported by CMA. Four generators entered into government-guaranteed PRE-renewable projects and received carbon credits equal to the emissions saved. Carbon credits were converted into potential carbon credit revenue and used to evaluate the financial viability of renewable projects. Carbon measures are now financial, but still short-term and adhoc in nature. In trialling energy efficiency initiatives, renewable generators adopted direct physical measures of paper and energy used/saved, but did not convert them into emissions increased/saved. The measurement was limited to a few business units, such as retail or corporate.

Therefore, CMA still played a limited role during this period. Short-term and monetarised carbon measures were used to evaluate renewable projects falling under the PRE scheme. Thermal generators used physical CMA to evaluate risk and to benchmark. However, carbon measures were now more detailed to enable comparisons between locations. CMA was not used to make key decisions around identifying carbon reduction/investment opportunities or facilitating low-carbon product development.

Period 3. CMA became increasingly complex from 2006 in response to the various anticipatory strategic initiatives. As carbon tax was cancelled, the companies expected 
the introduction of an ETS, so carbon prices were used to calculate potential carbon liability or carbon-related cost savings. These monetary carbon accounts took increasing prominence in CMA and management discussions. Carbon information was now communicated to a wide range of functions, including product design, R\&D, production, and marketing to involve the whole organisation in risk assessment and strategic planning.

Thermal generators converted emissions into potential financial liability. Boards of directors and top management teams asked for quarterly updates on emissions levels and international carbon prices to enable planning. CMA covered internally-generated emissions and externally-generated carbon prices and involved both generation and trading. While thermal generators focused on accounts for unsustainability, renewable generators primarily used accounts for sustainability. Measures of saved emissions and avoided carbon costs were used. All generators collected and communicated carbon information, including long-term, future-oriented information, in more timely ways.

In non-generation functions, measures for electricity, waste, paper consumption, and staff travel were now converted into carbon measures. Renewable generators also measured emissions savings and reduction targets, involving all generation and nongeneration departments. RenewC also monitored the number and costs of carbon offsets purchased to achieve carbon neutrality certification. Consistent with a more proactive strategy, renewable generators now covered more functions, whereas Thermal generators involved only one or two functional unit. Renewable generators used sustainability accounts, whereas thermal generators accounted for unsustainability.

Period 4. With the announcement of the ETS, generators implemented CC action plans. They used carbon measures to support a wide range of decisions and designed new carbon measures. Accounts for sustainability, namely avoiding carbon emissions/costs, became prominent. With the "reality of carbon pricing" confirmed by the ETS, the generators decided to "incorporate potential carbon prices and costs in evaluating alternative generation proposals and energy efficiency projects" (senior manager, ThermalB). All project appraisals now incorporated carbon costs.

Generators now monitored international carbon prices to time the sales of PREgranted carbon credits or purchase offsets for carbon neutrality certification (renewable generators) or future ETS compliance (thermal generators). Carbon information was now used in decision-making rather than the risk analysis/planning prevalent in Period 3. Three generators (Thermal A, RenewC and RenewE) committed to substantial new renewable generation projects. Carbon information was collected more regularly, used routinely, was future-oriented, supporting both shortterm/operational (credit purchase) and long term/strategic (generation investment) decisions.

Carbon neutrality was pursued by three generators (ThermalA, RenewC, and RenewD), with measurement and offsetting applying to non-generation functions only (ThermalA), the parent organisation only (RenewD), and the whole organisation, including purchased electricity, subsidiaries and contractors (RenewC) respectively. An overall budget was assigned for internal energy efficiency and carbon neutrality programmes. Although ThermalB and RenewE did not pursue carbon neutrality, they also set carbon reduction targets. Additionally, in two thermal generators and RenewD, a separate budget was established for carbon trading. RenewC also set up a 
'visual carbon budget' for each department/business unit so that 'unit managers could be held responsible for that budget and emission reduction targets' (Senior manager). These different types of carbon budgets were designed to facilitate carbon reduction, and therefore accounts for sustainability.

A new type of measure, emissions intensity, was now favoured, with thermal generators measuring intensity/Gwh produced, and renewable generators using nongeneration emissions intensity/employee. They considered intensity to "provide a more practical picture of carbon performance [that] is easier for benchmarking... and decision-making" (Manager, ThermalB). This method separated average carbon performance from increased activity levels, and was regarded as more controllable, as explained by a manager from RenewE: "our company is in a growth stage, it is very hard to reduce absolute emissions levels. The focus should be on how to reduce the carbon footprint per each employee or Gwh". Intensity measures were also used for assessing performance and decisions on energy efficiency projects and production optimisation. Intensity measures were used in the company-wide performance measurement system by four companies (ThermalA, ThermalB, RenewC and RenewD) and became a personal KPI of a production manager (ThermalB) and of a $\mathrm{CC}$ manager (RenewC). All of the companies reported a reduction in emissions intensity during this period.

Period 5: The uncertainty of carbon pricing and the new regulatory uncertainty meant that long-term, non-financial carbon implications were now considered, rather than direct carbon costs. New regulatory uncertainties meant that CMA moved from financial to non-financial measures.

Carbon pricing was still important in carbon credit decisions. ThermalB proactively purchased carbon credits in Period 4, because of relatively low international carbon prices. Now, they used carbon prices to decide whether to hold or sell credits. ThermalA and ThermalC had a 'wait-and-see' reactive strategy, in which carbon price information was monitored but not acted upon, due to the regulatory uncertainties.

With the cancellation of carbon neutrality programmes, non-generation carbon measures were no longer used in management decisions. Some generators switched to the measuring and assuring carbon emissions only. Energy efficiency efforts and related budgets were now reduced and often merged into operational budgets. Evaluating managers on carbon indicators were cancelled, removing incentives to reduce emissions. Carbon intensity was still monitored and reported, but not used in decision-making. This represents accounts for unsustainability, with carbon information now mostly non-financial and less timely than in Period 4.

The three state-owned generators now focussed on cost control and improved profitability. The CMA now emphasised cost controls, tight budgeting, and performance evaluation. Efficiency gains now justified cut-backs in carbon-related initiatives.

Table 7 summarises the changes in the design and use of CMA by the five generators during the five periods. 
Table 7: Change in accounting practice for climate change issues over time in the 5 generators

\begin{tabular}{|c|c|c|c|c|c|}
\hline & Period 1 & Period 2 & Period 3 & Period 4 & Period 5 \\
\hline RMS & Stable & $\begin{array}{l}\text { Anticipatory, } \\
\text { proactive }\end{array}$ & $\begin{array}{l}\text { Anticipatory, } \\
\text { proactive, creative }\end{array}$ & $\begin{array}{l}\text { Anticipatory, proactive, } \\
\text { creative }\end{array}$ & Reactive \\
\hline $\begin{array}{l}\text { CMA } \\
\text { Types of } \\
\text { account }\end{array}$ & $\begin{array}{l}\text { Physical } \\
\text { accounts } \\
\text { for } \\
\text { unsustain- } \\
\text { ability (T) }\end{array}$ & $\begin{array}{l}\text { Physical } \\
\text { accounts for } \\
\text { unsustainability } \\
(\mathrm{T}) \\
\text { Monetarised } \\
\text { accounts for } \\
\text { sustainability } \\
(\mathrm{T}+\mathrm{R}) \\
\end{array}$ & $\begin{array}{l}\text { Physical and } \\
\text { monetised accounts } \\
\text { for unsustainability } \\
\text { (T) } \\
\text { Physical and } \\
\text { monetised accounts } \\
\text { for sustainability (R) }\end{array}$ & $\begin{array}{l}\text { Physical and monetised } \\
\text { accounts for } \\
\text { sustainability and } \\
\text { unsustainability }(\mathrm{T}+\mathrm{R})\end{array}$ & $\begin{array}{l}\text { Physical accounts } \\
\text { for } \\
\text { unsustainability } \\
(\mathrm{T}+\mathrm{R})\end{array}$ \\
\hline \multirow[t]{2}{*}{ Uses } & $\begin{array}{l}\text { No use in } \\
\text { decision- } \\
\text { making }\end{array}$ & $\begin{array}{l}\text { Risk assessment } \\
\text { and strategic } \\
\text { planning } \\
\text { Benchmarking }\end{array}$ & $\begin{array}{l}\text { Internal coordination } \\
\text { Strategic planning } \\
\text { Investment } \\
\text { evaluation, EE } \\
\text { projects }\end{array}$ & $\begin{array}{l}\text { Investment evaluation, } \\
\text { EE } \\
\text { Carbon credit purchase } \\
\text { Carbon neutrality } \\
\text { Performance evaluation }\end{array}$ & $\begin{array}{l}\text { Carbon credit } \\
\text { decisions } \\
\text { Little use in } \\
\text { operational } \\
\text { decision-making } \\
\end{array}$ \\
\hline & $\begin{array}{l}\text { Not part of } \\
\text { Board } \\
\text { agenda }\end{array}$ & $\begin{array}{l}\text { Ad hoc } \\
\text { reporting to } \\
\text { Board }\end{array}$ & $\begin{array}{l}\text { Quarterly reporting } \\
\text { to Board }\end{array}$ & $\begin{array}{l}\text { Quarterly reporting to } \\
\text { Board }\end{array}$ & $\begin{array}{l}\text { Not part of Board } \\
\text { agenda }\end{array}$ \\
\hline $\begin{array}{l}\text { Key } \\
\text { measure }\end{array}$ & $\begin{array}{l}\text { Total } \\
\text { generation } \\
\text { emissions } \\
(\mathrm{T})\end{array}$ & $\begin{array}{l}\text { Total generation } \\
\text { emissions }(\mathrm{T}) \\
\text { Emissions by } \\
\text { plant and type } \\
(\mathrm{T}) \\
\text { Revenue from } \\
\text { carbon credits } \\
(\mathrm{T}+\mathrm{R}) \\
\text { Non-generation: } \\
\text { Physical non- } \\
\text { carbon } \\
\text { measures }(\mathrm{R})\end{array}$ & $\begin{array}{l}\text { Total generation } \\
\text { emissions or non- } \\
\text { generation emissions } \\
\text { (T) } \\
\text { Emissions liability } \\
\text { (T) } \\
\text { Carbon prices (T) } \\
\text { Amount of avoided } \\
\text { emissions (R) } \\
\text { Carbon cost savings } \\
\text { (R) } \\
\text { Reduction targets } \\
\text { (R) }\end{array}$ & $\begin{array}{l}\text { Emissions intensity per } \\
\text { Gwh }(\mathrm{T}) \text { or per } \\
\text { employee }(\mathrm{R}) \\
\text { Total generation } \\
\text { emissions }(\mathrm{T}) \\
\text { Emissions liability }(\mathrm{T}) \text {, } \\
\text { Amount of avoided } \\
\text { emissions }(\mathrm{T}+\mathrm{R}) \\
\text { Carbon cost savings } \\
(\mathrm{T}+\mathrm{R}) \\
\text { Carbon prices }(\mathrm{T}+\mathrm{R}) \\
\text { Offsetting costs }(\mathrm{R}) \\
\text { Carbon budget }(\mathrm{T}+\mathrm{R}) \\
\text { Reduction targets }(\mathrm{T}+\mathrm{R})\end{array}$ & $\begin{array}{l}\text { Non-financial } \\
\text { implications of } \\
\text { carbon }(\mathrm{T}+\mathrm{R}) \\
\text { Carbon price }(\mathrm{T}) \\
\text { Total generation } \\
\text { and non- } \\
\text { generation } \\
\text { emissions }(\mathrm{T}+\mathrm{R})\end{array}$ \\
\hline $\begin{array}{l}\text { Regularity } \\
\text { of use }\end{array}$ & Ad hoc & Ad hoc & $\begin{array}{l}\text { Routine integration } \\
\text { in decision-making }\end{array}$ & $\begin{array}{l}\text { Routine integration in } \\
\text { decision-making }\end{array}$ & Ad hoc \\
\hline $\begin{array}{l}\text { Carbon } \\
\text { offset }\end{array}$ & None & None & $\begin{array}{l}\text { Headquarter/retail } \\
\text { only }\end{array}$ & Organisation-wide & None \\
\hline
\end{tabular}

Table 7 shows an increase in the importance of accounting measures until period 4 and a marked reduction thereafter.

\section{DISCUSSION OF RESULTS}

\subsection{Organisational Strategies to fit climate change risk exposure and regulatory uncertainty}

Our results suggest a strong fit between $\mathrm{CC}$ risk exposure and risk management strategy. An anticipatory strategy appears to be most appropriate when there is moderate risk/opportunity and increasing (moderate/high) uncertainty. An anticipatory strategy focuses on lobbying, risk assessment, and strategic planning. It also involves operational changes to prepare for compliance with the (measurement, reporting, and surrendering) requirements of $\mathrm{CC}$ regulations. A reactive strategy is preferred when there is uncertainty about detail/timing of $\mathrm{CC}$ regulations, or when uncertainty emanates from rapid changes in $\mathrm{CC}$ policy or carbon prices. A reactive 
strategy is also appropriate when CC issues are considered to be non-strategic and posing a low, but potentially changing, risk to the organisation. A reactive approach ensures the ability to remain competitive and responsive to unpredictable changes.

A stable strategy is an appropriate response when carbon issues are seen as nonstrategic, posing no risk, and offering no opportunities. Even when carbon prices are low, such conditions may never return, given the current global awareness and public expectations around carbon issues. Therefore, a stable strategy is not advisable anymore.

Proactive strategies are appropriate when there are significant carbon-related opportunities. Creative strategies are suitable when companies perceive high levels of $\mathrm{CC}$ risks, such that carbon issues could affect organisational survival, legitimacy, and competitiveness in the short and the long term. Moving towards a renewable or lowered-carbon focus may be targeted.

Both our theoretical framework and the findings suggest that companies do not always adhere to the same strategy. We find that depending on the specific combination of perceived risks and opportunities, a company's strategic responses may not fit a single box in a framework. For example, in Period 3 thermal generators pursued anticipatory strategies to prepare for the short-term compliance requirements of the impending ETS, while also undertaking elements of a creative strategy by researching carbon capture technologies. Similarly, renewable generators anticipated an ETS through lobbying activities while adopting green marketing and energy efficiency initiatives to capture the opportunities associated with increasing carbonawareness (a combination of anticipatory and proactive strategies).

Table 8 compares our findings of the generators' strategy response to $\mathrm{CC}$ risk exposure with the predictions from the prior literature in Table 2. In period 1, the generators responded as predicted. In period 2, they were anticipatory, because of the need to respond to the impending regulations. However, from Period 3 onwards, their responses were less proactive than suggested by Table 2 . These differences are caused by regulatory uncertainty, the additional dimension that our paper adds to the literature. Regulatory uncertainty relates to the inability to estimate the likelihood of the regulation being introduced or changed, and the nature and the timing of any changes. In period 2, companies perceived the regulatory uncertainty to be low, with a carbon tax being expected. Thermal generators were more proactive than expected, as the announced carbon tax suggested that renewable investments would provide an economic advantage, and they decided to invest in PRE-scheme renewable projects.

In period 3, companies perceived the regulatory uncertainty to be higher and their strategy became more cautious than predicted. Apart from RenewC, the generators did not change their generation or investment strategies. Even in Period 4 when the ETS was announced, the thermal generators increased renewable investments, but still held on to their traditional assets. The focus was more on lobbying and preparing for future compliance than on substantive changes. This is because of uncertainties regarding policy direction and regulatory detail. Finally, in Period 5 with the delay of the ETS, the companies chose a reactive strategy, abstaining from significant carbon reduction initiatives. 
Table 8: Comparison between expected responses and actual responses of generators

\begin{tabular}{|l|l|l|l|l|l|}
\hline & Period 1 & Period 2 & Period 3 & Period 4 & Period 5 \\
\hline $\begin{array}{l}\text { Expected } \\
\text { response }\end{array}$ & $\begin{array}{l}\text { Stable } \\
(\mathrm{T})\end{array}$ & $\begin{array}{l}\text { Anticipatory } \\
(\mathrm{T}) \\
\text { Anticipatory/ } \\
\text { proactive (R) }\end{array}$ & $\begin{array}{l}\text { Anticipatory/ } \\
\text { creative (T) } \\
\text { Proactive (R) }\end{array}$ & $\begin{array}{l}\text { Creative (T) } \\
\text { Proactive/ } \\
\text { anticipatory (R) }\end{array}$ & $\begin{array}{l}\text { Anticipatory } \\
(\mathrm{T}+\mathrm{R})\end{array}$ \\
\hline $\begin{array}{l}\text { Actual } \\
\text { response }\end{array}$ & $\begin{array}{l}\text { Stable } \\
(\mathrm{T})\end{array}$ & $\begin{array}{l}\text { Anticipatory/ } \\
\text { proactive } \\
(\mathrm{T}+\mathrm{R})\end{array}$ & $\begin{array}{l}\text { Anticipatory/ } \\
\text { creative (T) } \\
\text { Anticipatory/ } \\
\text { Proactive (R) }\end{array}$ & $\begin{array}{l}\text { Anticipatory/ } \\
\text { proactive/ } \\
\text { creative (T+R) }\end{array}$ & $\begin{array}{l}\text { Reactive } \\
(\mathrm{T}+\mathrm{R}) \\
\text { Creative } \\
\text { (ThermalB) }\end{array}$ \\
\hline $\begin{array}{l}\text { Reason for } \\
\text { difference }\end{array}$ & & $\begin{array}{l}\text { Low } \\
\text { uncertainty }\end{array}$ & High uncertainty & $\begin{array}{l}\text { Medium } \\
\text { uncertainty }\end{array}$ & $\begin{array}{l}\text { High } \\
\text { uncertainty }\end{array}$ \\
\hline
\end{tabular}

Whereas most of the stage-model sustainability literature assumes that companies will take ever more proactive environmental strategies over time, we show that companies will de-emphasise sustainability under certain conditions. They chose a wait-and-see (reactive) strategy to await certainty on regulatory details.

Boiral (2006) suggests that "companies tend to maintain the status quo and not react as long as they are not obliged to do so" (p.323). We deduct from this statement that companies will engage a proactive carbon strategy under conditions of regulatory certainty. However, we show that regulatory uncertainty is not always met by a reactive strategy. The impact of regulatory uncertainty cannot be considered in isolation but rather in conjunction with perceived market opportunities and $\mathrm{CC}$ risk. Low uncertainty can increase the level of perceived risk or opportunity and can motivate companies to undertake more proactive carbon reduction strategies. Although high uncertainty generally causes a more reactive approach, companies can still proactively invest, e.g. RenewC in period 3 perceived high uncertainty but still decided to move to a fully-renewable business model. In period 5, despite the ETS delay and review, ThermalB retired some thermal generation early and prioritised renewables. This was because management perceived regulatory uncertainty to be short-term and they were intent on managing their image as a "dirty", irresponsible generator in the long term. Management also considered carbon pricing to be the new reality, implying that thermal assets would become less competitive. Therefore, the concern over CC risk overrode regulatory uncertainty and led ThermalB to undertake creative strategies. Therefore, the impact of regulatory uncertainty on investment decisions depends on the interactions among regulatory uncertainty, market opportunities, and CC risk.

We therefore modify our original depiction (Figure 1) to reflect the importance of regulatory uncertainty in strategic choice (see Figure 2).

Our study also shows the differences and commonalities between companies in their strategic responses. The thermal and renewable generators adopt different strategies due to their contingencies (asset bases and emission levels). Generally, renewable generators use more proactive strategies as they perceive more CC-related market opportunities, while thermal generators focus on anticipatory and creative strategies to prepare for future compliance. A stable strategy was common to all generators in the first time period. In the second, third and fourth time periods, thermal and renewable generators employed similar strategic responses, namely a combination of 
anticipatory, proactive and creative strategies. In addition, thermal generators undertook proactive initiatives, such as developing energy efficiency products, or pursuing carbon neutrality. Renewable generators also invested in creative initiatives such as R\&D in new renewable technologies. During the fifth time period, four of the generators pulled back to reactive strategies, while one employed a creative strategy to take advantage of perceived long-term opportunities. Therefore, a company's strategic response is a consequence of the perceived risks and opportunities, influenced by contingencies such as the company's asset and knowledge base.

Figure 2: Modified risk, strategy, accounting framework

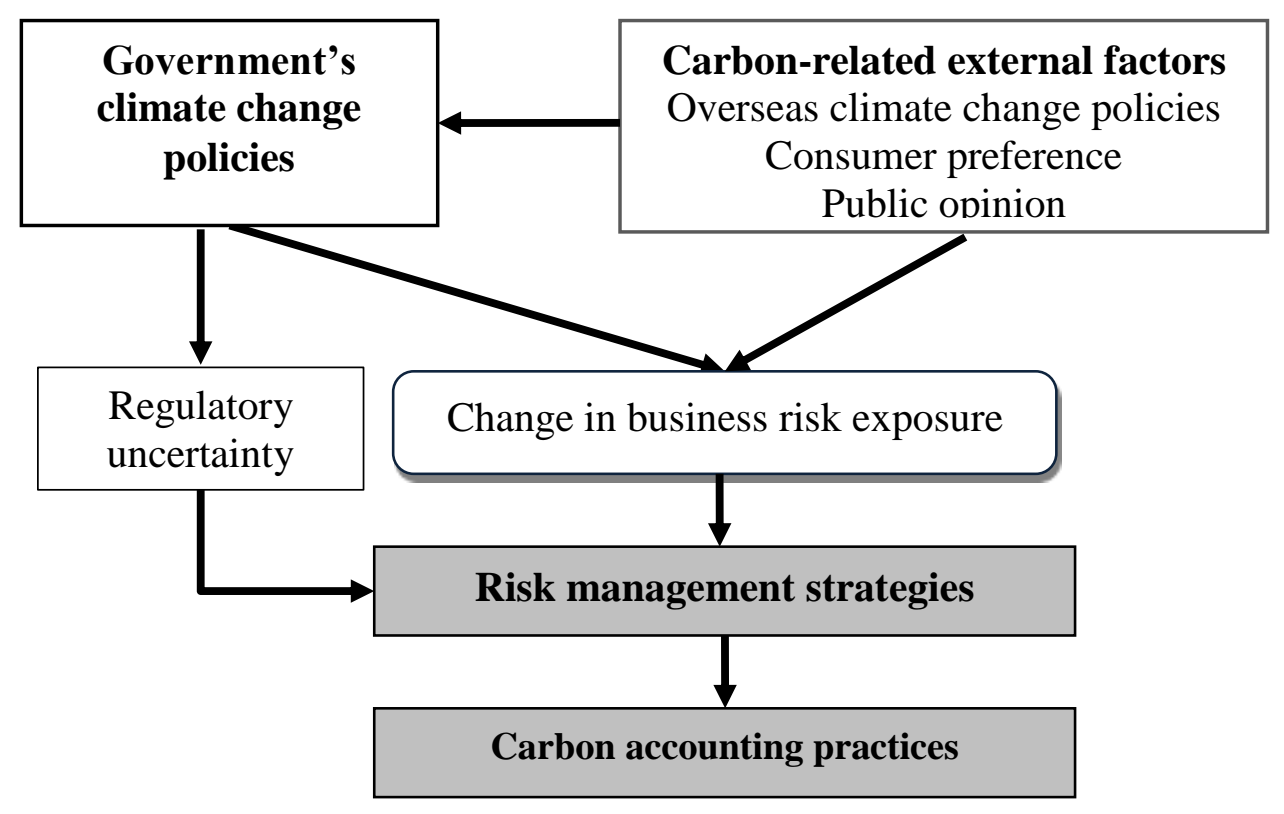

\subsection{The Appropriate Carbon Accounting for Each Risk Management Strategy}

Consistent with contingency theory, our results show that each risk management strategy will involve a different mixture of carbon accounts, indicators and uses. In a stable strategy, physical accounts for unsustainability were used to comply with existing reporting requirements, but not for decision-making. A reactive strategy requires similar CMA, but whereas a stable strategy focus on short-term, past-oriented information, a reactive strategy also require long-term and non-financial carbon measures. This is because while regulatory uncertainty makes it difficult to calculate and integrate monetarised carbon information in decision-making, generators expect societal pressures to increase carbon regulations. Physical accounts for unsustainability continue to be important in an anticipatory strategy when these accounts are used for internal reporting and benchmarking. With this strategy, carbon information is monetarised (e.g. carbon liability, carbon prices) to inform risk assessment and strategic planning. The collection of carbon information is ad-hoc in these three strategies. This information is either not part of the board agenda (stable and reactive) or only reported and discussed in an ad-hoc manner (anticipatory). 
The more proactive strategies (proactive and creative) require a focus on futureoriented accounts for sustainability, such as measures of emissions/cost avoided, or costs of offsetting. These accounts are used to justify key carbon reduction decisions, e.g. investment evaluations, and energy efficiency and carbon neutrality projects. There is an increasing focus on monetarised measures, enabling the development of a business case for projects. CMA for a proactive strategy focuses on a few years ahead (carbon neutrality, energy efficiency), whereas a creative strategy focuses on decades ahead (asset investments). CMA in proactive and creative strategies include both financial and non-financial measures. Reduction targets, carbon budgets and offsets are features of the CMA in proactive and creative strategies. Carbon information is collected regularly and used routinely in decision-making, including at board level.

CMA supports strategy and differs depending on the chosen strategy. More reactive strategies rely on past-oriented, ad-hoc, short-term physical accounts for unsustainability that is not used in decision-making, while more proactive strategies rely on future oriented, regularly compiled, long-term monetarised accounts for sustainability that is extensively used in decision-making.

We show that CMA changes over time. However, existing CMA is often maintained after the introduction of new types, lying dormant until new strategies make them useful again. For example, carbon intensity was not new, but was never reported to top management until they recognised its usefulness in a proactive strategy. Also, during period 5, the period 4 CMA was largely retained. The CMA information was now used to monitor rather than to actively manage.

Our findings add new insights regarding the design, use, and role of CMA. First, similar to previous research, we find companies design and use physical and monetised carbon information accounts for unsustainability as well as accounts for sustainability to support various internal decisions and coordinate different functions in implementing business and CC strategies (Burritt and Schaltegger, 2011; Schaltegger and Csutora, 2012). We show that CMA use is determined by the risk management strategies adopted. Extensive CMA use in strategic planning and decision-making is only observed in proactive and creative strategies, while limited CMA use and emissions monitoring are prevalent in more reactive strategies.

Second, we find CMA plays different roles in supporting risk management strategies. CMA is used for compliance purposes in a stable strategy (Stechemesser \& Guenther, 2012), and to monitor external developments in a reactive strategy. CMA supports continuous improvement and provides information for decision-making in a proactive strategy (Henri \& Journeault, 2010). The role of CMA to increase staff awareness and organisational learning is most prominent in a creative strategy. Although CMA plays a role in carbon performance, we show that CMA does not always lead to carbon reduction as assumed by the prior literature (Ratnatunga \& Balachandran, 2009; Schaltegger \& Csutora, 2012; Stechemesser \& Guenther, 2012). Past-oriented unsustainability accounts that is not used in decision-making has little impact on carbon performance. Future-oriented, long-term sustainability accounts that is extensively used in decision-making are most effective in carbon mitigation. In evidence, during the periods of proactive/creative strategies, emissions reductions were largest, while emissions were unchanged or increased during the more reactive periods.

Table 9 modifies and extends the theoretical framework introduced in Table 2, based on our findings and the discussion in this section. Table 9 summarises the 
contingency-based relationship between risk management strategy, $\mathrm{CC}$ exposure and CMA design and use. This modified framework extends the literature in two ways, namely i) adding regulatory uncertainty as an important, separate element, and ii) identifying the appropriate CMA for each strategy. The framework maps choice of strategy to CC risk, market opportunities, regulatory uncertainty, and appropriate CMA to support strategy.

Table 9: Modified framework for the fit between risk management strategy, climate change exposure and CMA design and use

\begin{tabular}{|c|c|c|c|c|c|}
\hline & Stable & Reactive & Anticipatory & Proactive & Creative \\
\hline $\begin{array}{l}\text { Climate } \\
\text { change } \\
\text { exposure }\end{array}$ & $\begin{array}{l}\text { Low risk } \\
\text { Low } \\
\text { opportunity } \\
\text { Low } \\
\text { uncertainty }\end{array}$ & $\begin{array}{l}\text { High/extreme } \\
\text { uncertainty } \\
\text { Low but } \\
\text { changing risk } \\
\text { Low } \\
\text { opportunity }\end{array}$ & $\begin{array}{l}\text { Moderate risk } \\
\text { and/or moderate } \\
\text { opportunity } \\
\text { Moderate/high } \\
\text { uncertainty }\end{array}$ & $\begin{array}{l}\text { Low/moderate } \\
\text { risk } \\
\text { High } \\
\text { opportunity } \\
\text { Low } \\
\text { uncertainty }\end{array}$ & $\begin{array}{l}\text { High risk } \\
\text { Moderate } \\
\text { opportunity } \\
\text { Low } \\
\text { uncertainty }\end{array}$ \\
\hline $\begin{array}{l}\text { Strategic } \\
\text { orientation }\end{array}$ & Internal & $\begin{array}{l}\text { Internal and } \\
\text { external }\end{array}$ & $\begin{array}{l}\text { Internal and } \\
\text { external }\end{array}$ & External & $\begin{array}{l}\text { Internal and } \\
\text { external }\end{array}$ \\
\hline $\begin{array}{l}\text { Activity } \\
\text { focus }\end{array}$ & $\begin{array}{l}\text { Pollution } \\
\text { control }\end{array}$ & $\begin{array}{l}\text { Policy } \\
\text { oversight }\end{array}$ & $\begin{array}{l}\text { CC risk } \\
\text { assessment and } \\
\text { planning } \\
\text { Lobbying }\end{array}$ & $\begin{array}{l}\text { Low-carbon } \\
\text { product } \\
\text { Green } \\
\text { marketing } \\
\text { Carbon } \\
\text { neutrality/ } \\
\text { energy } \\
\text { efficiency }\end{array}$ & $\begin{array}{l}\text { R\&D in low- } \\
\text { carbon } \\
\text { technology } \\
\text { Shift towards } \\
\text { low-carbon } \\
\text { production }\end{array}$ \\
\hline $\begin{array}{l}\text { CMA } \\
\text { design }\end{array}$ & $\begin{array}{l}\text { Physical } \\
\text { accounts for } \\
\text { unsustain- } \\
\text { ability } \\
\text { Short-term, } \\
\text { Past oriented }\end{array}$ & $\begin{array}{l}\text { Physical } \\
\text { accounts for } \\
\text { sustainability; } \\
\text { Long term and } \\
\text { short-term } \\
\text { oriented }\end{array}$ & $\begin{array}{l}\text { Physical and } \\
\text { monetarised } \\
\text { accounts for } \\
\text { unsustainability }\end{array}$ & $\begin{array}{l}\text { Monetarised } \\
\text { accounts for } \\
\text { sustainability } \\
\text { Future } \\
\text { oriented, } \\
\text { short-term or } \\
\text { long term }\end{array}$ & $\begin{array}{l}\text { Physical and } \\
\text { monetarised } \\
\text { accounts for } \\
\text { sustainability } \\
\text { Future oriented } \\
\text { and long term }\end{array}$ \\
\hline $\begin{array}{l}\text { CMA } \\
\text { information } \\
\text { collection } \\
\text { and use }\end{array}$ & $\begin{array}{l}\text { Ad hoc } \\
\text { collection } \\
\text { Little use }\end{array}$ & $\begin{array}{l}\text { Ad hoc } \\
\text { collection } \\
\text { Little use }\end{array}$ & $\begin{array}{l}\text { Ad hoc } \\
\text { collection } \\
\text { Ad hoc use }\end{array}$ & $\begin{array}{l}\text { Routine } \\
\text { collection } \\
\text { Extensive use }\end{array}$ & $\begin{array}{l}\text { Routine } \\
\text { collection } \\
\text { Extensive use }\end{array}$ \\
\hline
\end{tabular}

CMA - Carbon management accounting

\section{CONCLUSION}

This study develops a theoretical framework (Table 2), based on a literature review, to examine five New Zealand electricity generators by way of a case study based on indepth interviews and archival data. We specifically focus on i) the strategies generators adopt to respond to $\mathrm{CC}$ risks, and ii) consequent changes in carbon management accounting. Our case study informs the original framework and leads to a revised theoretical framework (Table 9). In addition, we modify our original metaview of causal effects (Figure 1) to emphasise the important role we found regulatory uncertainty to play (Figure 2).

The study makes several contributions to the literature. First, we develop a framework that connects $\mathrm{CC}$ risks and opportunities with appropriate strategic responses. This framework essentially builds on the idea that the mixture of $\mathrm{CC}$ risks and market 
opportunities is the key driver of an organisation's risk management strategy. Using this framework, our findings suggest contingency fit between $\mathrm{CC}$ exposure and risk management strategies. As the CC exposure increases, companies move from stable and anticipatory strategies to proactive strategies. Further, there was a shift over time from internal to external functions in implementing these strategies, reflecting the fact that the $\mathrm{CC}$ exposure was primarily driven by external stakeholder pressures and policy changes. However, companies revert to reactive strategies as $\mathrm{CC}$ exposure reduces. The modified framework based on our empirical findings also connects $\mathrm{CC}$ exposure with regulatory uncertainty and CMA design and use. This framework helps to theorise, explain, and predict the strategic and CMA responses of organisations exposed to different combinations of $\mathrm{CC}$ risk, opportunity and uncertainty.

Our second contribution is to show the impact of policy and regulatory uncertainty on perceived $\mathrm{CC}$ exposure and risk management strategy. Our case study companies were more conservative in their strategies than previously suggested in the literature because they were aware of the inherent uncertainty in CC policies. High levels of regulatory uncertainty will cause companies to adopt less proactive strategies than would be predicted under conditions of less uncertainty. Regulatory uncertainty needs to be considered within the context of perceived $\mathrm{CC}$ risks and market opportunities as the interaction between these three factors will determine companies' strategic stance.

Third, we provide evidence regarding the design, use and role of CMA in relation to risk management strategy. We find that the types of CMA do not constitute an automatic response to $\mathrm{CC}$ issues, but are driven by the strategies an organisation decides to adopt in response to the CC risks. Reactive strategies are associated with short-term, past-oriented physical and monetarised accounts for unsustainability, and by ad-hoc collection, reporting and use of carbon information. More proactive strategies are supported by long-term, future-oriented, physical and monetarised accounts for sustainability, and the routine collection and use of carbon information in decision-making. CMA plays different roles depending on the strategy adopted: regulatory compliance in a stable strategy; external oversight in a reactive strategy; risk assessment in an anticipatory strategy; continuous improvement in a proactive strategy; organisational learning in a creative strategy; and strategic renewal in proactive and creative strategies. We also identify that future oriented accounts for sustainability are more effective for carbon reduction than past oriented accounts for unsustainability.

Our study contributes to the emerging body of literature that addresses the role of CMA in the integration of sustainability into business strategies and promoting a lower carbon business model. By using contingency theory and a risk perspective to examine this relationship, we highlight that risk profile influences strategic direction, which in turn influences the choice of CMA. Given that risk profile changes with changes in regulation and public awareness, these influences remain dynamic, explaining the need for regular, sometimes frequent changes to CMA. These findings will be relevant to managers and accounting practitioners who are participating in, or leading their organisations in, their transformations towards a low-carbon future. Our findings improve our understanding of the strategies used under different levels of CC exposure, and the CMA appropriate to these strategies.

We contribute to theory by showing that CC risk leads to strategic choices that dictate accounting choice, and by constructing a theoretical framework that is based on both 
prior literature and our study's findings. This theoretical framework could be used in future research, including in different industries and different countries.

Environmental regulation, such as an ETS, can cause substantial business risks, implying a need for an appropriate strategic response. This study can assist businesses in this changing context, by improving understandings through our conceptual/theoretical framework and our analysis of best practice.

\section{REFERENCES}

Aragón-Correa, J. A., \& A. Rubio-López, E. (2007). Proactive Corporate Environmental Strategies: Myths and Misunderstandings. Long Range Planning, 40(3), 357-381.

Arena, M., Arnaboldi, M., \& Azzone, G. (2010). The organizational dynamics of Enterprise Risk Management. Accounting, Organizations and Society, 35(7), 659-675.

Arjaliès, D.-L., \& Mundy, J. (2013). The use of management control systems to manage CSR strategy: A levers of control perspective. Management Accounting Research, 24(4), 284-300.

Atkins, J., \& Maroun, W. (2015). Integrated reporting in South Africa in 2012: Perspectives from South African institutional investors. Meditari Accountancy Research, 23(2), 197-221.

Atkins, J. F., Solomon, A., Norton, S., \& Joseph, N. L. (2015). The emergence of integrated private reporting. Meditari Accountancy Research, 23(1), 28-61.

Azzone, G., \& Bertelè, U. (1994). Exploiting green strategies for competitive advantage. Long Range Planning, 27(6), 69-81.

Bebbington, J., \& Larrinaga-Gonzalez, C. (2008). Carbon Trading: Accounting and Reporting Issues. European Accounting Review, 17(4), 697-717.

Bhimani, A. (2009). Risk management, corporate governance and management accounting: Emerging interdependencies. Management Accounting Research, 20(1), 2-5.

Boiral, O. (2006). Global Warming: Should Companies Adopt a Proactive Strategy? Long Range Planning, 39(3), 315-330.

Braun, V., \& Clarke, V. (2006). Using thematic analysis in psychology. Qualitative Research in Psychology, 3(2), 77.

Brownell, P. (1985). Budgetary Systems and the Control of Functionally Differentiated Organizational Activities. Journal of Accounting Research, 23(2), 502-512.

Burchell, S., Clubb, C., Hopwood, A., Hughes, J., \& Nahapiet, J. (1980). The roles of accounting in organizations and society. Accounting, Organizations and Society, 5(1), $5-27$.

Burritt, R., \& Schaltegger, S. (2014). Accounting towards sustainability in production and supply chains. The British Accounting Review, 46(4), 327-343.

Burritt, R., Schaltegger, S., \& Zvezdov, D. (2011). Carbon management accounting: explaining practice in leading German companies. Australian Accounting Review, 21(1), 80-98.

Buysse, K., \& Verbeke, A. (2003). Proactive environmental strategies: a stakeholder management perspective. Strategic Management Journal, 24(5), 453-470.

CERES. (2007). Climate Risk Disclosure by the S\&P 500: Report for the Carbon Disclosure Project: Investor Network on Climate Risk (INCR).

Chapman, C. S. (1998). Accountants in organisational networks. Accounting, Organizations and Society, 23(8), 737-766.

Chapple, L., Clarkson, P. M., \& Gold, D. L. (2013). The cost of carbon: Capital market effects of the proposed emission trading scheme (ETS). Abacus.

Chenhall, R. H. (2006). Theorizing contingencies in management control systems research. Handbooks of management accounting research, 1, 163-205. 
Chenhall, R. H., \& Langfield-Smith, K. (2003). Performance measurement and reward systems, trust, and strategic change. Journal of Management Accounting Research, $15,117-143$.

Committee of Sponsoring Organizations of the Treadway Commission (COSO). (2004). Enterprise Risk Management Framework. New York: COSO.

Covaleski, M. A., \& Dirsmith, M. W. (1988). The use of budgetary symbols in the political arena: An historically informed field study. Journal of Financial Economics, 13(1), 124.

Deloitte. (2007). The Risk Intelligent Energy company: Weathering the Storm of Climate Change. Risk Intelligence Series.

Denzin, N. (2009). The research act: A theoretical introduction to sociological methods: Aldine De Gruyter.

Derchi, G. B., Burkert, M., \& Oyon, D. (2013). Environmental Management Accounting Systems: A Review of the Evidence and Propositions for Future Research. In L. Songini, A. Pistoni \& C. Herzig (Eds.), Accounting and Control for Sustainability (Studies in Managerial and Financial Accounting) (Vol. 26, pp. 197-229): Emerald Group Publishing Limited.

Dhanda, K. K., \& Hartman, L. P. (2011). The ethics of carbon neutrality: a critical examination of voluntary carbon offset providers. Journal of Business Ethics, 100(1), $119-149$.

Dutton, J. E., \& Duncan, R. B. (1987). The creation of momentum for change through the process of strategic issue diagnosis. Strategic Management Journal, 8(3), 279-295.

Elkington, J. (2004). Enter the Triple Bottom Line. In A. Henriques \& J. Richardson (Eds.), Triple Bottom Line (pp. 1-17). London: Earthscan.

Engels, A. (2009). The European Emissions Trading Scheme: An exploratory study of how companies learn to account for carbon. Accounting, Organizations and Society, 34(34), 488-498.

Ezzamel, M. (1990). The impact of environmental uncertainty, managerial autonomy and size on budget characteristics. Management Accounting Research, 1, 181-197.

Flick, U. (2009). An introduction to qualitative research: Sage Pubns Ltd.

Gond, J.-P., Grubnic, S., Herzig, C., \& Moon, J. (2012). Configuring management control systems: Theorizing the integration of strategy and sustainability. Management Accounting Research, 23(3), 205-223.

Griffin, P., Lont, D., \& Sun, Y. (2012). The relevance to investors of greenhouse gas emission disclosures. UC Davis Graduate School of Management Research Paper(01-11).

Hart, L. (1995). A Natural-Resource-Based View of the Firm. The Academy of Management Review, 20(4), 986-1014.

Henri, J.-F., \& Journeault, M. (2010). Eco-control: The influence of management control systems on environmental and economic performance. Accounting, Organizations and Society, 35(1), 63-80.

Hodgson, P. (2005). Speech announcing carbon tax detail. Wellington: Minister of Climate Change Issues, New Zealand Government.

Hoffmann, V., Trautmann, T., \& Hamprecht, J. (2009). Regulatory uncertainty: A reason to postpone investments? Not necessarily. Journal of Management Studies, 46(7), 12271253.

Hopwood, A., Unerman, J., \& Fries, J. (2010). Accounting for sustainability: Practical insights: Earthscan.

Hoque, Z., Covaleski, M. A., \& Gooneratne, T. N. (2013). Theoretical triangulation and pluralism in research methods in organizational and accounting research. Accounting, Auditing \& Accountability Journal, 26(7), 1170-1198.

Hunt, C. B., \& Auster, E. R. (1990). Proactive environmental management: avoiding the toxic trap. Sloan Management Review, 31(2), 7-18.

Jansson, A.., Nilsson, F., \& Rapp, B. (2000). Environmentally driven mode of business development: a management control perspective. Scandinavian Journal of Management, 16(3), 305-333. 
Jeswani, H. K., Wehrmeyer, W., \& Mulugetta, Y. (2008). How warm is the corporate response to climate change? Evidence from Pakistan and the UK. Business Strategy and the Environment, 17(1), 46-60.

Khlif, H., Hussainey, K., \& Achek, I. (2015). The effect of national culture on the association between profitability and corporate social and environmental disclosure: a metaanalysis. Meditari Accountancy Research, 23(3), 296-321.

Knight, F. (1921). Risk, Uncertainty and Profit. New York AM Kelley.

Kolk, A., \& Levy, D. (2001). Winds of Change::: Corporate Strategy, Climate change and Oil Multinationals. European Management Journal, 19(5), 501-509.

Kolk, A., Levy, D., \& Pinkse, J. (2008). Corporate Responses in an Emerging Climate Regime: The Institutionalization and Commensuration of Carbon Disclosure. European Accounting Review, 17(4), 719-745.

Kolk, A., \& Pinkse, J. (2005). Business responses to climate change: identifying emergent strategies. California Management Review, 47(3), 6-20.

Langfield-Smith, K. (2005). What do you we know about management control systems and strategy. In C. S. Chapman (Ed.), Controlling strategy: management, accounting and performance measurements (pp. 63-83): Oxford University Press.

Lovell, H., Bulkeley, H., \& Liverman, D. (2009). Carbon offsetting: sustaining consumption? Environment and Planning A, 41(10), 2357-2379.

Lund, P. (2007). Impacts of EU carbon emission trade directive on energy-intensive industries--Indicative micro-economic analyses. Ecological Economics, 63(4), 799806.

Malmi, T., \& Brown, D. A. (2008). Management control systems as a packageOpportunities, challenges and research directions. Management Accounting Research, 19(4), 287-300.

Maroun, W. (2015). Culture, profitability, non-financial reporting and a meta-analysis: Comments and observations. Meditari Accountancy Research, 23(3), 322-330.

Massa, L., Farneti, F., \& Scappini, B. (2015). Developing a sustainability report in a small to medium enterprise: process and consequences. Meditari Accountancy Research, 23(1), 62-91.

MBIE. (2013a). Data tables for electricity. Available from Ministry of Business, Innovation, and Employment http://www.med.govt.nz/sectors-industries/energy/energymodelling/data/electricity. Retrieved 16 July 2015.

MBIE. (2013b). Energy green house gas emissions. Wellington: Ministry of Business, Innovation, and Employment.

Merchant, K. A. (1990). The effects of financial controls on data manipulation and management Myopia. Accounting Organizations and Society, 15(4), 297-313.

MfE. (2009). Summary of the proposed changes to the NZ ETS. Wellington: Ministry for the Environment, NZ Government.

MfE. (2014). United Nations Framework Convention on Climate Change. Wellington: Ministry for the Environment.

Mikes, A. (2009). Risk management and calculative cultures. Management Accounting Research, 20(1), 18-40.

Miller, G., Dingwall, R., \& Murphy, E. (2004). Using qualitative data and analysis reflections on organizational research. In D. Silverman (Ed.), Qualitative research: Theory, Method and Practice (2 ed., pp. 325-340). London: Sage.

Modell, S. (2010). Bridging the paradigm divide in management accounting research: The role of mixed methods approaches. Management Accounting Research, 21(2), 124129.

Mundy, J. (2010). Creating dynamic tensions through a balanced use of management control systems. Accounting, Organizations and Society, 35(5), 499-523.

Ottman, J. A. (1992). Industry's response to green consumerism. Journal of Business Strategy, 13(4), 3-7.

Paape, L., \& Speklé, R. F. (2012). The Adoption and Design of Enterprise Risk Management Practices: An Empirical Study. European Accounting Review, 21(3), 533-564. 
Parker, D. (2005). Press release: Carbon tax will not go ahead in 2007. Wellington: Minister of Climate Change Issues, New Zealand Government.

Parker, D. (2008). Historic climate change legislation passes. New Zealand Government Media Release. Wellington: Minister for Climate Change.

Pérez, E. A., Ruiz, C. C., \& Fenech, F. C. (2007). Environmental management systems as an embedding mechanism: a research note. Accounting, Auditing \& Accountability Journal, 20(3), 403-422.

Power, M. (2004). The risk management of everything. The Journal of Risk Finance, 5(3), 5865 .

Ratnatunga, J., \& Balachandran, K. R. (2009). Carbon Business Accounting: The Impact of Global Warming on the Cost and Management Accounting Profession. Journal of Accounting, Auditing \& Finance, 24(2), 333-355.

Reid, E. M., \& Toffel, M. W. (2009). Responding to public and private politics: Corporate disclosure of climate change strategies. Strategic Management Journal, 30(11), 11571178 .

Reinaud, J. (2005). Industrial Competitiveness under the European Union Emission Trading scheme International Energy Agency Information Paper.

Rugman, A. M., \& Verbeke, A. (1998). Corporate strategies and environmental regulations: an organizing framework. Strategic Management Journal, 19(4), 363-375.

Russo, M. V., \& Fouts, P. A. (1997). A Resource-Based Perspective on Corporate Environmental Performance and Profitability. The Academy of Management Journal, 40(3), 534-559.

Sandelin, M. (2008). Operation of management control practices as a package-A case study on control system variety in a growth firm context. Management Accounting Research, 19(4), 324-343.

Schaltegger, S. (2011). Sustainability as a driver for corporate economic success. Society and Economy, 33(1), 15-28.

Schaltegger, S., \& Csutora, M. (2012). Carbon accounting for sustainability and management. Status quo and challenges. Journal of Cleaner Production, 36(November), 1-16.

Scipioni, A., Manzardo, A., Mazzi, A., \& Mastrobuono, M. (2012). Monitoring the carbon footprint of products: a methodological proposal. Journal of Cleaner Production, 36(0), 94-101.

Sharma, S. (2000). Managerial Interpretations and Organizational Context as Predictors of Corporate Choice of Environmental Strategy. The Academy of Management Journal, 43(4), 681-697.

Simons, R. (1991). Strategic orientation and top management attention to control systems. Journal of Financial Economics, 12(1), 49-62.

Stead, J. G., \& Stead, W. E. (2008). Sustainable strategic management: an evolutionary perspective. International Journal of Sustainable Strategic Management, 1(1), 62-81.

Stechemesser, K., \& Guenther, E. (2012). Carbon accounting: a systematic literature review. Journal of Cleaner Production, 36(0), 17-38.

Steger, U. (1993). The greening of the board room: how German companies are dealing with environmental issues. In K. Fischer \& J. Schot (Eds.), Environmental Strategy for Industry (pp. 147-166). Washington, DC: Island Press.

Stein, M., \& Khare, A. (2009). Calculating the carbon footprint of a chemical plant: a case study of Akzonobel. Journal of environmental assessment policy and management, 11(03), 291-310.

Stent, W., \& Dowler, T. (2015). Early assessments of the gap between integrated reporting and current corporate reporting. Meditari Accountancy Research, 23(1), 92-117.

Tang, Q., \& Luo, L. (2014). Carbon management systems and carbon mitigation. Australian Accounting Review, 24(1), 84-98.

Tsai, W.-H., Shen, Y.-S., Lee, P.-L., Chen, H.-C., Kuo, L., \& Huang, C.-C. (2012). Integrating information about the cost of carbon through activity-based costing. Journal of Cleaner Production, 36(0), 102-111. 
Warren, C. A. B. (2002). Qualitative intervewing. In J. Gubrium \& J. Holstein (Eds.), Handbook of interview research: context and meaning (pp. 83-101). Thousand Oaks, CA: Sage.

Weinhofer, G., \& Hoffmann, V. H. (2010). Mitigating climate change-how do corporate strategies differ? Business Strategy and the Environment, 19(2), 77-89.

Woods, M. (2009). A contingency theory perspective on the risk management control system within Birmingham City Council. Management Accounting Research, 20(1), 69-81.

Yin, R. K. (2003). Case Study Research: design and methods. Thousand Oaks: Sage Publications Inc. 


\section{Appendix A: Main semi-structured interview questions}

1. What are the risks and opportunities that the different climate change policies might bring, or have brought, to your organisation? Do you think such risks and opportunities change over time?

2. What strategic responses have been taken by your organisation to respond to these risks and opportunities and manage organisational performance? Can you give me an example of such responses in different areas of the business?

3. Do you think the focus/importance on each of the above areas, or the alternative strategies, has changed due to the various changes in the climate change-related risks and opportunities?

4. How do you implement these climate change-related strategic responses? What are the key human and non-human resources that are allocated to climate change areas?

5. How do you measure, monitor and manage carbon emissions? How does this change over time?

6. How do you disseminate carbon information inside the organisation what types of decisions does such information assist? At which level of management is carbon information used?

7. What sort of carbon information is disclosed to external stakeholders? Is there consistency between the carbon information disclosed externally and that used internally?

8. What objectives (or roles) do you perceive carbon accounting information and systems fulfil within your organisation? 